\title{
PRAVNO USTROJSTVO NOGOMETNIH KLUBOVA U SOCIJALISTIČKOJ JUGOSLAVIJI I HRVATSKOJ S OSVRTOM NA RADNOPRAVNI STATUS PROFESIONALNIH NOGOMETAŠA
}

Vladimir Iveta*

\author{
UDK 349.2:796 \\ https://doi.org/10.30925/zpfsr.39.2.12 \\ Ur.: 31. listopada 2017. \\ Pr.: 9. svibnja 2018. \\ Stručni rad
}

\begin{abstract}
Sažetak
Nogometni klubovidanas su većinom udrugeili trgovačka društva, a profesionalni nogometaši na globalnoj razini imaju status radnika ili, rjeđe, samostalne sportske djelatnosti. U socijalističkoj Jugoslaviji i Hrvatskoj sport se temeljio na načelima amaterizma i socijalističkog samoupravljanja. Od šezdesetih se godina 20. stoljeća profesionalizam u jugoslavenskom nogometu legalizira, a 1970-tih u potpunosti se afirmirao i prevladao pravne i društveno-političke okvire koji su bili predviđeni za amaterski sport. Klubovi su postali organizacije koje osim sportske obavljaju i gospodarsku djelatnost. Ovim radom prikazuje se pokušaj Nogometnog saveza Jugoslavije i republičkih i pokrajinskih saveza za pronalaskom rješenja kod nastale suprotnosti između profesionalizma $i$ vladajućeg sustava samoupravnog socijalizma i udruženog rada. U radu se daje prikaz pravne regulative $i$ analiziraju prijedlozi koje su davali nogometni savezi $i$ klubovi za promjenom statusa profesionalnih klubova i nogometaša. Pokazuje se kako Nogometni savez nije uspio sam pronaći odgovarajuće rješenje te se za regulaciju statusa igrača kao radnika čekalo donošenje relevantnog zakona. Prilikom pisanja koristila se izvorna građa čiji su stvaratelji bili Nogometni savez Jugoslavije i Nogometni savez Hrvatske te savezni i republički propisi koji su bili relevantni za uređenje naznačene materije.
\end{abstract}

Ključne riječi: pravni status nogometnog kluba, Nogometni savez Jugoslavije, radno-pravni status nogometaša, samoupravljanje, udruženi $\mathrm{rad}$.

\footnotetext{
* Vladimir Iveta, dipl. iur., Hrvatski nogometni savez; vladimir.iveta@hns-cff.hr.
} 


\section{1. $U$ VOD}

U Republici Hrvatskoj ponovno je u tijeku rasprava o novom Zakonu o sportu, a Središnji državni ured za šport osnovao je radnu skupinu za izradu nacrta prijedloga Zakona o sportu.

Aktualni Zakon o sportu ${ }^{1}$ od svog je donošenja izazivao mnogobrojne polemike koje su dosegle vrhunac nakon usvajanja Zakona o izmjenama i dopuna Zakona o sportu ${ }^{2}$ kojim se zakonodavac umiješao u autonomiju sportskih udruga i dijelu tih udruga propisao sastav skupštine, pritom u samome obrazloženju Zakona, prema mišljenju autora, ne navodeći nikakve razloge, a kamoli racionalne i opravdane.

U sjeni tih rasprava koje su se vodile oko prevlasti u nogometnom sportu, ostalo je pitanje ustrojstva i pravnog oblika sportskih klubova, pa time i onih nogometnih.

Sukladno važećem zakonu, sportski klubovi mogu se osnovati ili ustrojiti kao udruge ili sportska dionička društva. Bez obzira na pravni status, klubovi mogu biti amaterski ili profesionalni. Hrvatski nogometni savez (dalje: HNS) svojim je Pravilnikom o statusu nogometnih klubova ${ }^{3}$ utvrdio da se u Prvoj hrvatskoj nogometnoj ligi mogu natjecati samo profesionalni klubovi. U Drugoj hrvatskoj nogometnoj ligi, Prvoj nogometnoj ligi za žene i Prvoj malonogometnoj ligi mogu se natjecati profesionalni i amaterski klubovi. U svim ostalim ligama mogu se natjecati samo amaterski klubovi.

$\mathrm{Na}$ klubove-udruge, osim ako Zakonom o sportu nije drukčije određeno, primjenjuju se odredbe Zakona o udrugama, ${ }^{4}$ a na klubove koji su sportska trgovačka društva odnose se odredbe Zakona o trgovačkim društvima. ${ }^{5}$ Čini se, sudeći prema objavljenoj procjeni učinaka propisa, ${ }^{6}$ da se niti u novom Zakonu o sportu neće bitnije promijeniti tako uspostavljena struktura sportskih klubova. Uostalom, ako promatramo nogomet, u velikoj većini europskih zemalja jednaka je ili slična situacija u pogledu statusa nogometnih klubova.

Tako u SR Njemačkoj licencu za sudjelovanje u Prvoj Ligi (DFL Deutsche Fussball Liga) mogu dobiti klubovi organizirani kao udruge i različita društva kapitala ako u njemu većinski paket drži klub-udruga (Statut Njemačkog nogometnog saveza zove ga „matični klub“). ${ }^{7}$ Takvu je odluku donio Njemački nogometni savez i nije određena državnim propisima. U praksi to znači da klub udruga sadrži profesionalnu komponentu (seniorsku ekipu koja se natječe u Prvoj ligi) ustrojenu kao trgovačko društvo.

1 Zakon o sportu, Narodne novine, br. 71/06, 150/08, 124/10, 124/11, 86/12, 94/13 i 85/15.

2 Zakon o izmjenama i dopunama Zakona o sportu, Narodne novine, br. 85/15.

3 Glasnik Hrvatskog nogometnog saveza (dalje: HNS), Zagreb, br. 57/08.

4 Zakon o udrugama, Narodne novine, br. 74/14, 70/17.

5 Zakon o trgovačkim društvima, Narodne novine, br. 111/93, 34/99, 121/99, 52/00, 118/03, 107/07, 146/08, 137/09, 125/11, 152/11, 111/12, 68/13 i 110/15.

6 Procjena učinaka u Zakon o sportu, http://www.sdus.hr/dokumenti-i-informacije/javnosavjetovanje/javno-savjetovanje-o-nacrtu-prijedloga-iskaza-o-procjeni-u\%C4\%8Dinakapropisa-za-zakon-o-sportu/. Pristup ostvaren 11. 09. 2017.

7 Statut Njemačkog nogometnog saveza, https://www.dfb.de/fileadmin/_dfbdam/128750-02 Satzung. Pristup ostvaren 11. 09. 2017. 
U Španjolskoj je Zakonom o sportu ${ }^{8}$ utvrđeno da klubovi mogu imati pravni oblik osnovnog kluba (španj. club deportivo elemental), temeljnog kluba (španj. club deportivo bâsico) ili sportskog dioničkog društva (španj. sociedad anónima deportiva). Prva dva oblika su udruge koje se međusobno razlikuju u načinu osnivanja, broju članova, sudjelovanju u natjecanju, načinu upravljanja itd. ${ }^{9}$ Većina klubova u prvoj španjolskoj ligi su sportska dionička društva, osim dva najveća, F.C. Barcelona i C.F. Real Madrid i Athletic Club de Bilbao, koji su temeljni klubovi.

Engleski klubovi mogu biti organizirani kao udruženja s pravnom osobnošću ili bez nje (engl. Unicorporated association) te u različitim formama trgovačkog društva. ${ }^{10}$

U zemljama s kojima dijelimo nogometnu i društveno-političku prošlost, kao što su Srbija i Bosna i Hercegovina, situacija je vrlo slična. U Srbiji je Zakonom o sportu ${ }^{11}$ utvrđeno da sportske organizacije mogu imati status udruge (sportsko udruženje) ili trgovačkog društva (sportsko privredno društvo). Jednako je rješenje primijenjeno u Bosni i Hercegovini, a koje je regulirano Zakonom o sportu u Bosni u Hercegovini. ${ }^{12}$

U svim promatranim primjerima samo je u Španjolskoj i Hrvatskoj, koja je preuzela španjolski model Zakonom o sportu iz 2006. godine, državnim propisom određeno da sportski klub koji je trgovačko društvo mora imati formu dioničkog društva. U ostalim zemljama je prepušten slobodan izbor klubovima da odluče u kojoj će se formi trgovačkog društva organizirati.

U bivšoj se Jugoslaviji krajem sedamdesetih godina 20. stoljeća vodila rasprava o preustroju nogometnih klubova (ne i klubova ostalih sportova). Jedan od prijedloga bio je vrlo blizu, uz uvažavanje specifičnosti jugoslavenskog samoupravnog društva, modela koji je danas većinski. Naime, postavljalo se pitanje mogu li se nogometni klubovi, osim kao udruženja građana, formirati i kao organizacije udruženog rada, dakle s gospodarstvenim ustrojem.

Koristeći se propisima i drugim pisanim materijalima Nogometnog saveza Jugoslavije (NSJ) i na njih oslonjenih propisa i dokumenata Nogometnog saveza Hrvatske (NSH), relevantnim saveznim i republičkim državnim propisima i političkoteoretskim dokumentima cilj je ovog rada prikazati pravni status nogometnih klubova u Socijalističkoj Federativnoj Republici Jugoslaviji (SFRJ) s naglaskom na pokušaj preustroja klubova s profesionalnim igračima u okviru Zakona o udruženom radu (ZUR). ${ }^{13}$ Radi objašnjenja konteksta u kojem se odvijala rasprava dat će se i prikaz pravnog statusa i društveno-političkog okruženja jugoslavenskog, osobito profesionalnog, nogometa u sedamdesetim godinama 20. stoljeća. ${ }^{14}$

8 Ley del deporte 10/1990, de 15 de octubre, BOE num. 249/1990.

9 Bermejo Vera, J. (ur.), Guía Juridica del Fútbol aficionado, Madrid, Real Federación Española de Fútbol, 1998., str. 43 i 51.

10 Club Structures. A Guide to Club Stuctures for National League system and other Football Clubs, London, Football Association - Charles Russell, 2010.

11 Zakon o sportu, Službeni list Republike Srbije, br. 24/11.

12 Zakon o sportu u Bosni i Hercegovini, Službeni glasnik, BiH, br. 168/08.

13 Zakon o udruženom radu, Službeni list SFRJ, br. 53/76.

14 O statusu nogometaša u uvjetima udruženog rada vidjeti u Kovačić, D., Nogometni profesionalci u udruženom radu, Zagreb, Časopis za suvremenu povijest, 47-1/2016, str. 67-95. 


\section{JUGOSLAVENSKI NOGOMET SEDAMDESETIH GODINA - PRAVNI OKVIR}

Nakon burnog predratnog razdoblja obilježenog sukobima oko sjedišta Jugoslavenskog nogometnog saveza, otpora centralizaciji, dijeljenja i spajanja nacionalnih liga, jugoslavenski je nogomet nakon Drugog svjetskog rata u novom društveno-političkom okruženju organiziran putem Nogometnog saveza Jugoslavije koji je osnovan 8. rujna 1948. u Beogradu. ${ }^{15}$ Sukladno federativnom uređenju države, i nacionalni nogometni savez činili su republički i pokrajinski nogometni savezi. Uz nogometne saveze, članovi su bili Savez nogometnih sudaca Jugoslavije i Savez nogometnih trenera Jugoslavije te od 1966. i Udruženje klubova Prve savezne lige. ${ }^{16}$

Nogometni klubovi bili su osnovni elementi nogometne organizacije. S obzirom na proklamirano načelo socijalističkih vlasti o sportu kao amaterskom i radi promicanja tjelesne kulture među radnicima i građanima ${ }^{17}$ nije se previše obraćalo pažnje na pravno ustrojstvo sportskih klubova. Naime, oni su trebali biti pod kontrolom društveno-političkih zajednica (političkih teritorijalnih jedinica - kotareva, općina, mjesnih zajednica) i pripadajućeg Socijalističkog saveza radnog naroda (SSRN, ranije Narodna fronta). S obzirom na monopolistički politički i društveni položaj (čak zajamčen i Ustavom) jedine političke stranke, Saveza komunista Jugoslavije (SKJ), potrebno je razmotriti i njezin formalni stav prema sportu. U Programu SKJ koji je usvojen na VII Kongresu 1958., i koji je do raspada SKJ ostao važeći program, fizička kultura se spominje svega dva puta, u kontekstu sustava odgoja i obrazovanja i kod afirmacije omladine u društvu te u njemu stoji da:

„Razne društvene organizacije, koje u određenim aktivnostima okupljaju veliki deo omladine i dece (fiskulturne, naučno-tehničke, kulturno-prosvetne, ferijalne, izviđačke i druge organizacije), od velikog su značaja ne samo zato što zadovoljavaju radne potrebe i interesovanje svojih članova, već i zbog toga što doprinose formiranju socijalističke ličnosti mladog čoveka. ${ }^{\text {18 }}$

SKJ je, znači, u svom Programu zauzeo stajalište da tjelesna kultura ima prosvjetnu, odgojnu i zdravstvenu ulogu. Međutim, politika je bila vrlo svjesna popularnosti sporta, osobito nogometa, među ,širokim narodnim masama“, a vezano uz to i njegovog utjecaja. Nogomet je često bio stvar međunarodnog prestiža i afirmacije te ponekad i „dokazivanja“ ideološke ispravnosti, kao u poznatim utakmicama između

U navedenome radu naglasak je na društveno-političkom prikazu te može uspješno poslužiti kao nadopuna pravnom pregledu iz ovog članka.

15 „Nogometni savez Jugoslavije“, u: Kramer, F., Klemenčić, M. (ur.), Nogometni leksikon, Zagreb, Leksikografski zavod Miroslav Krleža, 2004., str. 366.

16 Loc. cit.

$17 \mathrm{O}$ amaterskom sportu, tjelesnoj kulturi i stavovima vlasti prema sportu u ranim godinama socijalizma vidjeti Klasić, H., Fiskultura u službi naroda. Uloga tjelesnog odgoja u stvaranju jugoslavenskog socijalističkog društva 1945-1952., u: Duda, I. (ur.), Stvaranje socijalističkog čovjeka, Zagreb, Srednja Europa, 2017., str. 201-220 i Stanić, I., Sport za svakoga. Sportske aktivnosti radničke klase u Hrvatskoj od 1945. do početka 1960-ih, Zagreb, Historijski zbornik, vol. $69,1 / 17$, str. 121-139.

18 VII. Kongres Saveza komunista Jugoslavije, Program SKJ, Beograd, Kultura, 1958., str. 411. 
reprezentacija Jugoslavije i SSSR-a na Olimpijskim igrama 1952. u Helsinkiju. ${ }^{19}$

Temeljem takvog formalnog odnosa prema sportu, nogometni klubovi osnivani su kao udruženja građana, kao najjednostavniji oblik organiziranja. Takvo je stanje ostalo i nakon što je, poslije dužeg razdoblja prešutno odobravanog, profesionalizam u nogometu i službeno priznat aktima NSJ-a. ${ }^{20}$ Međutim, tijekom cijelog trajanja socijalističke Jugoslavije u NSJ-u je uvijek bio istican primat amaterskog sporta/ nogometa, a profesionalizam je bio trpljen kao neizbježno zlo. ${ }^{21}$ Primjerice, na IV. redovnoj Konferenciji ${ }^{22}$ NSJ-a održanoj u prosincu 1977. u Kumrovcu, pod točkom Aktuelna pitanja i zadaci fudbalske organizacije u pripremi platforme XI Kongresa Saveza komunista Jugoslavije istaknuto je da:

„Briga za masovnost i amaterizam ostaje i dalje platforma naše fudbalske organizacije i njezin politički imperativ. Omasovljenje fudbalskog sporta, u čemu su ostvareni zapaženi rezultati, prema tome, ostaje i dalje u prvom planu. “23

U promatranom razdoblju, sedamdesetih godina 20. stoljeća, jugoslavenski je socijalistički eksperiment došao u novu fazu. Naime, 21. veljače 1974. Savezna Skupština usvojila je novi Ustav SFRJ. ${ }^{24}$ Osim daljnjeg jačanja konfederalnih elemenata državnog ustrojstva, procesa koji je započeo u razdoblju od 1967. do 1971. donošenjem amandmana na Ustav iz $1963 .{ }^{25}$, novi je Ustav produbio sustav samoupravljanja u sve elemente političkog, gospodarskog i društvenog života i otvorio put konceptu udruženog rada.

Međutim, za razliku od Ustava Socijalističke Republike Hrvatske (SRH) koji je donesen neposredno nakon saveznog Ustava, ${ }^{26} \mathrm{u}$ obimnom Ustavu SFRJ koji se sastojao od 406 članaka i 10 opsežnih uvodnih osnovnih načela, uopće se ne spominju sport ili njegova tadašnja istoznačnica fizička kultura. ${ }^{27}$ Stoga ustavni temelj za

19 Više vidjeti u: Klasić, H.,The Tito-Stalin Football War, Zagreb, Radovi - Zavod za hrvatsku povijest, vol. 48, 1/2016, str. 387-404.

20 O kasnijem formalnom ulasku profesionalizma u nogomet ostalih socijalističkih zemalja na primjeru Čehoslovačke vidjeti: Duke,V., Kickern Glasnost. Professionalisierung und Kommerzialisierung im tschechoslowakischen Fussball, u: Horak, R., Leders. W. (ur.), Beiträge zur europäischen Fussballkultur, Wien Promedia, 1991., str. 95-103.

21 Za izvore takvog stava više vidjeti: Prozumenščikov, M., Bemerkungen zum sowjetischen Fussball unter Stalin und Chruščev, u: Giessauf, J., Iber, Walter M., Knoll, H. (ur.), Fussball, Macht und Diktatur, Innsbruck, Studienverlag, 2014., str. 137-160.

22 Konferencija je bila najviše tijelo upravljanja NSJ. U Nogometnom savezu Hrvatske, uz kraći prekid, za to je tijelo zadržan naziv skupština.

23 IV redovna Konferencija Fudbalskog saveza Jugoslavije, 17-18. 12. 1977., izvodi iz zapisnika. Beograd, Jugoslovenski fudbal, vanredni broj IV, Nogometni savez Jugoslavije, 1978., str. 15. (dalje: IV. Konferencija NSJ 1977.).

24 Ustav Socijalističke Federativne Republike Jugoslavije, Službeni list SFRJ, br. 9/74.

25 Vidjeti više u: Bilandžić, D., Historija Socijalističke Federativne Republike Jugoslavije, Zagreb, Školska knjiga, 1979., str. 373-381 i Bilandžić, D., Moderna hrvatska povijest, Zagreb, Golden marketing, 1990., str. 528-552.

26 Republički Ustav donesen je u Saboru SRH, 22. veljače 1974., Ustav Socijalističke Republike Hrvatske, Narodne novine, br. 8/74.

27 S obzirom na to da je idejni tvorac tog Ustava bio Edvard Kardelj zbog čijeg je nezanimanja za sport izmišljena i zanimljiva anegdota, ne čudi takav odnos prema sportu. Anegdota se odnosi na Kardeljevo reagiranje na prelazak Vladimira Beare iz Hajduka u beogradsku Crvenu 
organizaciju sportskih klubova trebamo naći u točki IV Osnovnih načela u uvodnom dijelu Ustava, odjeljku 10. koji glasi:

„Radi ostvarivanja i usklađivanja svojih interesa i samoupravnih prava u skladu s općim interesima socijalističkog društva, kao i radi vršenja određenih društvenih poslova i razvijanja raznovrsnih aktivnosti, radni ljudi i građani slobodno se udružuju u društveno-političke i druge društvene organizacije i udruženja građana, kao sastavni dio socijalističkog samoupravnog sistema."

Članak 167. stavak 1. Ustava potvrdio je, makar formalno, izneseno načelo:

„Zajamčena je sloboda štampe i drugih vidova informiranja i javnog izražavanja, sloboda udruživanja, sloboda govora i javnog istupanja, sloboda zbora i drugog javnog okupljanja.“

Formalnu zanemarenost sporta možemo utvrditi temeljem točke V. Osnovnih načela kada se u odjeljku 2. navodi da su:

„[...] obrazovanje, nauka i kultura bitan činilac razvoja socijalističkog društva, podizanja produktivnosti rada, razvoja stvaralačkih snaga ljudi i svestranog razvoja ličnosti $[\ldots]^{\text {" }}$

U ostalim općim aktima, primjerice u Ustavu SRH, točki V. Osnovnih načela, uz obrazovanje, znanost i kulturu u ovom kontekstu spominju se i tjelesna i tehnička kultura. Nadalje, sporta nema niti u točki III. 12. odjeljku Osnovnih načela Ustava SFRJ gdje se utvrđuje da

„Radni ljudi svoje lične i zajedničke potrebe i interese u oblastima obrazovanja, nauke, kulture, zdravstva i drugih društvenih djelatnosti, kao dijelovima jedinstvenog procesa društvenog rada, osiguravaju slobodnom razmjenom i udruživanjem svog rada s radom radnika u organizacijama udruženog rada u tim oblastima. Slobodnu razmjenu rada ostvaruju radni ljudi neposredno preko organizacija udruženog rada u okviru ili preko samoupravnih interesnih zajednica. Ovakvim odnosima osigurava se radnicima u tim djelatnostima jednak društveno-ekonomski položaj kao i drugim radnicima u udruženom radu."

Slično je ponovno regulirano u članku 16. stavku 1. i 2. Ustava, odnosno za samoupravne interesne zajednice u članku 52. Ustava. Međutim, kasnijim osnivanjem samoupravnih interesnih zajednica (SIZ) za fizičku kulturu, postalo je jasno da se sport svrstao među „druge društvene djelatnosti.“

Uz ustavno načelo slobode udruživanja u udruženja građana i društvene organizacije bio je vezan republički Zakon o udruženjima građana. U promatranom razdoblju u SRH važio je Zakon o udruženjima građana koji je Sabor donio 21. lipnja 1973. ${ }^{28}$ Člankom 3. tog Zakona utvrđuje se da:

„Građani mogu slobodno i dobrovoljno osnivati udruženja radi ostvarivanja svojih zajedničkih interesa i razvijanja kulturne, prosvjetne, umjetničke, naučne, zdravstvene, socijalne, fiskulturne, tehničke, humane i druge društvene aktivnosti.“

zvezdu. Naime, 1955. vratar Hajduka, reprezentativac Jugoslavije i član FIFA-ine selekcije Svijeta Vladimir Beara, prešao je u Crvenu zvezdu. Nezadovoljstvo u Splitu i Dalmaciji prema Beogradu bilo je takvo da je preraslo u politički problem. Kardelj je preuzeo na sebe smiriti situaciju i okupio je relevantne osobe iz politike i nogometa. Na početku je sastanka navodno upitao: „Pa dobro, zar je zaista tako važno da li taj Beara igra tenis u Splitu ili Beogradu?“

Zakon o udruženjima građana, Narodne novine, br. 26/73. 
Dakle, iz teksta Zakona nesumnjivo proizlazi da se sportski klubovi mogu osnivati kao udruženja građana. Udruženje je mogla osnovati skupina od najmanje deset punoljetnih državljana SFRJ, ${ }^{29}$ a udruženja su se radi ostvarivanja zajedničkih ciljeva mogla organizirati i udruživati u saveze i druge oblike udruživanja. ${ }^{30}$

Pomalo iznenađujuće, o udruženjima građana pozitivno se izjasnio i glavni ideolog Saveza komunista Jugoslavije Edvard Kardelj. Naime, u svom djelu Pravci razvoja političkog sistema socijalističkog samoupravljanja Kardelj piše:

„Značajno mesto u našem političkom sistemu ima i princip slobode udruživanja. I zaista, u nas postoji mnoštvo udruženja radnih ljudi i građana i društvenih organizacija najrazličitijeg tipa, među kojima su i takve koje u našem društvenom životu igraju značajnu društvenu i stručnu ulogu. [...] Razvoj socijalističkog samoupravnog društva zahteva negovanje i obogaćivanje individualnih sklonosti i interesovanja radnih ljudi i građana za razne društvene, humanitarne, socijalne, kulturne, naučne, tehničke, sportske i druge aktivnosti. Kroz ovakve aktivnosti vrši se povezivanje i ostvarivanje širih interesa radnih ljudi. [...] Prema tome, na društvene organizacije i udruženja treba da gledamo kao na konstitutivni deo našeg samoupravnog sistema. Jer i na te oblike udruživanja primenjuju se osnovna načela tog sistema $[\ldots]^{\text {‘31 }}$

Znači, razlozi zbog kojih se tražio drukčiji oblik ustrojstva za nogometne klubove, što ćemo vidjeti kasnije, nisu bili političke prirode, barem ne u većoj mjeri, odnosno udruženja građana nisu bila sama po sebi ideološki ,sumnjiva“.

Detaljniji status sportskih organizacija od Zakona o udruženjima građana utvrđivao je Zakon o fizičkoj kulturi koji je Sabor usvojio 18. prosinca 1974. ${ }^{32} \mathrm{U}$ poglavlju pod nazivom Društvene organizacije u oblasti fizičke kulture, u članku 27. Zakona stajalo je:

„Radi ostvarivanja i usklađivanja svojih interesa i samoupravnih prava u oblasti fizičke kulture u skladu s općim interesima socijalističkog društva te radi organiziranog razvijanja aktivnosti u oblasti fizičke kulture, radni ljudi i građani udružuju se i osnivaju društvene organizacije u oblasti fizičke kulture kao sastavni dio socijalističkog samoupravnog sistema.“

Društvenu organizaciju u oblasti fizičke kulture mogli su osnovati radnici u organizaciji udruženog rada, društveno-političke i društvene organizacije, mjesna zajednica, radni ljudi i građani. Kao cilj takvih društvenih organizacija bilo je utvrđeno djelovanje na omasovljavanju aktivnosti fizičke kulture i poticanje postizanja vrhunskih sportskih dostignuća. ${ }^{33}$ Kao osnovno načelo natjecanja uzet je amaterizam $^{34}$ te se i vrhunski sport zasnivao na načelima amaterizma. ${ }^{35}$ Iznimno, status profesionalnih sportskih organizacija i sportaša, njihova prava i obveze trebali su se utvrditi zakonom i društvenim dogovorom koji zaključuju organizacije fizičke

29 Ibid., čl. 6., st. 1.

30 Ibid., čl. 12., st. 1.

31 Kardelj, E., Pravci razvoja političkog sistema socijalističkog samoupravljanja, Beograd, Izdavački centar „Komunist“, Beograd, 1977., str. 213-214.

32 Zakon o fizičkoj kulturi, Narodne novine, br. 52/74.

33 Ibid., čl. 31.

34 Ibid., čl. 38. st. 1.

35 Ibid., čl. 40. st. 2. 
kulture republika i pokrajina. Pritom se profesionalni sport mogao razvijati samo u društvenim organizacijama fizičke kulture utvrđenim društvenim dogovorom saveza za fizičku kulturu republika i pokrajina. ${ }^{36}$

Primjećuje se da su klubovi imali pravni status udruženja građana (u Zakonu o udruženjima građana ne spominju se društvene organizacije), dok su prema Zakonu o fizičkoj kulturi bili tretirani kao društvene organizacije iz oblasti fizičke kulture. To znači da su se klubovi registrirali kao udruženja građana, a djelovali su kao društvena organizacija, pri čemu se između ta dva pravna konstrukta ne može utvrditi neka bitna razlika. Uostalom, kada se govorilo o udruživanju radnih ljudi i građana, najčešće su korištena oba pojma zajedno i ravnopravno. ${ }^{37}$ Zanimljivu formulaciju, koja izjednačava udruženja građana i društvene organizacije, daje Savezna Skupština Saveza za fizičku kulturu Jugoslavije u svojoj Rezoluciji o fizičkoj kulturi od 22. lipnja 1968.:

„Društvene organizacije za fizičku kulturu, kao dobrovoljna udruženja građana, su činioci koji ubuduće mogu znatno više pridonijeti ostvarivanju društvenih ciljeva u oblasti fizičke kulture naroda. Ove organizacije, u skladu s interesima svojih članova, treba da organiziraju zadovoljavanje potreba građana za fizičkom kulturom, i dalje da njeguju i podstiču vrhunska sportska dostignuća. “38

Ovakav je dvojni, i zapravo nedefinirani, status postojao do donošenja novog Zakona o društvenim organizacijama i udruženjima građana 1982. godine, o kojemu će u nastavku biti riječi. Zakon koji je trebao regulirati status profesionalnih klubova i sportaša nije nikada donesen, ali je zaključen društveni dogovor unutar nogometne organizacije.

Takvo je bilo statusno-pravno stanje nogometnih klubova u trenutku kada je, 17. travnja 1978. godine, Izvršni odbor NSJ na svojoj XXV redovnoj sjednici dao na javnu raspravu prednacrt Samoupravnog preobražaja nogometnog kluba.

\section{PROFESIONALNI NOGOMET - TEORIJA I PRAKSA}

Jedan od razloga pokretanja postupka pravnog preustroja bilo je i pitanje statusa profesionalnih nogometaša i klubova koji se natječu u profesionalnim ligama.

Kao što smo vidjeli, profesionalni nogomet je bio iznimka od pravila o amaterizmu u nogometu i sportu općenito. S obzirom na to da niti na saveznoj niti republičkoj razini nisu doneseni zakoni koji su trebali regulirati profesionalizam u sportu, sportske organizacije same su donosile odgovarajuće akte. Savez za fizičku

36 Ibid., čl. 43.

37 O tomu vidjeti npr. navedeni Kardeljev citat ili Teze Republičke Konferencije SSRN Hrvatske o mjestu i ulozi društvenih organizacija. Mjesto i uloga društvenih organizacija, Teze radne grupe Republičke konferencije SSRN Hrvatske, Zagreb, Službeni glasnik Saveza za fizičku kulturu Hrvatske, broj 89-90/1968., str. 3-5. U Tezama je istaknuto, između ostalog, da su društvene organizacije i udruženja građana specifičan oblik i integralni dio političkih sistema samoupravne neposredne demokracije, ali da velika većina njih nije integrirana kao sastavni i ravnopravni dio određene privredne i društvene djelatnosti (str. 4).

38 Savezna Skupština Saveza za fizičku kulturu Jugoslavije, Rezolucija o fizičkoj kulturi, Zagreb, Službeni glasnik saveza za fizičku kulturu Hrvatske, br. 89-90/1968., str. 1-2. 
kulturu Jugoslavije usvojio je smjernice za reguliranje statusa, prava i obveza igrača koji se u vidu zanimanja bave igranjem nogometa, a nogometni savezi su ih zatim razradili i implementirali u svoj sustav propisa i društvenih dogovora.

Ovdje valja odmah naglasiti da profesionalni nogometaš nije zasnivao radni odnos s klubom. U obveznom obrascu ugovora klub-igrač, koji je propisivao NSJ, izričito je stajalo da se tim ugovorom ne može zasnovati radni odnos. S druge strane, profesionalni nogometaš nije s nekom radnom organizacijom ili drugim subjektom bio u radnom odnosu. Status profesionalnih nogometaša mogao se, uz znatne ograde, podvesti pod, tzv. slobodna zanimanja čiji je status načelno bio utvrđen člankom 31 . Ustava SFRJ:

„Radni ljudi koji ličnim radom samostalno u vidu zanimanja obavljaju umjetničku ili drugu kulturnu, advokatsku ili drugu profesionalnu djelatnost imaju u načelu isti društveno-ekonomski položaj i u osnovi ista prava i obaveze kao i radnici u organizacijama udruženog rada."

Radni ljudi koji obavljaju neku od ovih djelatnosti mogu udruživati svoj rad i obrazovati privremene ili trajne radne zajednice, koje imaju u osnovi isti položaj kao i organizacije udruženog rada i u kojima imaju u osnovi ista prava i dužnosti kao i radnici u organizacijama udruženog rada.

Međutim, nameće se pitanje kakav je točno bio status profesionalnih nogometaša? $?^{39}$

U članku 17. Statuta NSJ-a donesenom 6. ožujka 1976., utvrđeno je da u natjecanjima Prve savezne lige uz igrače amatere sudjeluju i igrači nogometaši koji se u vidu zanimanja bave igranjem nogometa i koji za igranje nogometa mogu dobivati odgovarajuću novčanu naknadu. Pritom, profesionalni igrači u klubu su organizirali zajednicu nogometaša $u$ kojoj $u$ načelu ostvaruju ista prava i obveze kao i radnici $u$ udruženom radu. ${ }^{40}$

Konferencija NSJ-a dana 8. svibnja 1976. donijela je Pravilnik o statusu igrača (dalje: Pravilnik o statusu igrača NSJ-a). ${ }^{41}$ Prema članku 4. tog Pravilnika nogometaši se „po odnosu prema osnovnoj organizaciji-klubu“ dijele na amatere, amatere-vrhunske sportaše i igrače koji se u vidu zanimanja bave igranjem nogometa (profesionalci). Prema ovoj definiciji, kao i citiranim odredbama Statuta, igrači profesionalci bili bi osobe na koje se odnosi odredba članka 31. Ustava.

Kao amater bio je definiran ,[... [ igrač koji se kao član fudbalske organizacije aktivno bavi igranjem fudbala bez primanja naknade za igranje i koji ima pravo i

39 Pravi odgovor za status profesionalnih sportaša u ekipnim sportovima dan je zapravo tek prije nekoliko godina. Vidjeti članke Bilić, A. i Smokvina, V., Ugovori između profesionalnih nogometaša i klubova - ugovori radnog ili građanskog prava, Split, Zbornik radova Pravnog fakulteta u Splitu, vol. 49, 4/2012, str. 831-862 i Peročević, K., Pojam „radnika“ u pravu Europske unije, Zagreb, Zbornik radova Pravnog fakulteta u Zagrebu, vol. 67, 2/2017., str. 319-343.

40 Statut Fudbalskog saveza Jugoslavije, Zbirka propisa, Fudbalski savez Jugoslavije, Beograd, 1981.

41 Pravilnik o statusu igrača Fudbalskog saveza Jugoslavije, Zbirka propisa, Fudbalski savez Jugoslavije, Beograd, 1981., Arhiva Hrvatskog nogometnog saveza (dalje: Pravilnik o statusu igrača NSJ-a) 
obavezu da učestvuje u svim fudbalskim takmičenjima“". ${ }^{42}$

S druge strane, ,Status profesionalnog fudbalera može imati igrač koji ispunjava uslove predviđene ovim Pravilnikom za vreme dok se aktivno bavi igranjem fudbala u klubu koji se takmiči u najvišem stepenu fudbalskog takmičenja Jugoslavije““.43

Znači, profesionalci su mogli biti članovi samo klubova koji su se natjecali u Prvoj saveznoj ligi, a navedeno je utvrđeno i člankom 5. Pravilnika o statusu igrača NSJ-a.

Sukladno članku 17. Pravilnika o statusu igrača NSJ-a, profesionalni nogometaš može za igranje nogometa u klubu ostvariti ,osobni dohodak“ i druga primanja, a sve pod uvjetima utvrđenim Statutom i općim aktima kluba koji su morali biti usklađeni sa samoupravnom sporazumom klubova Prve savezne lige.

Profesionalni nogometaš pisanim je ugovorom zasnivao svoj odnos s klubom. ${ }^{44}$ Takav ugovor mogao se zaključivati s igračima koji su stariji od 18 godina i to u trajanju od najmanje četiri natjecateljske godine, a nakon isteka ugovora igrač je slobodan birati klub, dok za prelazak iz kluba u klub nema pravo na naknadu. ${ }^{45}$ Naravno, odredba o zabrani primanja naknade za prelazak iz kluba u klub redovno je bila ignorirana. ${ }^{46} \mathrm{~S}$ druge strane, kao što ćemo vidjeti $\mathrm{u}$ analiziranom primjeru ugovora igrač-klub, bila je moguća novčana i druga materijalna naknada za potpis novog ugovora s dosadašnjim klubom.

Člankom 18. Pravilnika o statusu igrača NSJ-a bila su utvrđena prava i obveze profesionalnih nogometaša. Takav je nogometaš bio član kluba i imao je prava koja pripadaju članu. Zatim, udruživao je svoju sportsku aktivnost u okviru posebne radne zajednice. Nogometaš je imao pravo upravljati poslovima kluba koji su u vezi s njegovom sportskom aktivnosti u zajednici i klubu te je mogao sudjelovati u raspodjeli namijenjenih za ,osobni dohodak“ $i$ druga primanja. Također je imao pravo ostvarivati prava temeljem socijalnog osiguranja - zdravstveno, mirovinsko i invalidsko te je imao pravo na određeno radno vrijeme, dnevni, tjedni i godišnji odmor.

Ugovorom između kluba i igrača utvrđivali su se igračevo pristupanje klubu i zajednici profesionalnih igrača, prihvaćanje statuta i drugih općih akata kluba, duljina trajanja ugovora, druga prava i obveze igrača sukladno samoupravnom sporazumu nogometnih klubova Prve savezne lige te sankcije za slučaj neizvršenja ugovora. ${ }^{47}$

U članku 21. Pravilnika o statusu igrača NSJ-a, pod naslovom „Raspodela ličnog dohotka“, utvrđeno je da se iz ukupnog dohotka kluba izdvaja poseban dio sredstava za osobne dohotke profesionalnih nogometaša sukladno Društvenom dogovoru

42 Pravilnik o statusu igrača NSJ-a 1976., cit., 6.

43 Ibid., cit., 16.

44 Ibid., cit., 23.

45 Ibid., cit., 25. i 28.

46 Primjerice, Dragan Holcer i Miroslav Vardić dobili su prijelaz iz niškog Radničkog u Hajduk u ljeto 1967. 7,5 milijuna starih dinara i stan, odnosno 5 milijuna starih dinara i garsonjeru, Sportske novosti od 10. 07. 1967., cit. prema: Gizdić, J., U Hajduk su došli i u povijest ušli, Split, HNK Hajduk, 2010., str. 52. Ponekad se, makar javno, posebno isticalo da je igrač u klub došao bez naknade, jer mu to prema propisima niti ne pripada. Na primjer, tako je objavljeno za vratara Ivana Budinčevića koji je u Hajduk došao iz Spartaka, Subotica da „Budinčeviću prema propisima ne pripada ni dinara.“, Slobodna Dalmacija od 03. 07. 1976., prema, ibid., str. 59.

47 Pravilnik o statusu igrača NSJ-a 1976, cit. 24. 
i samoupravnom sporazumu klubova Prve savezne lige. Radno vrijeme i odmor profesionalnog nogometaša, kao i broj utakmica koje može tijekom godine odigrati, utvrđivali su se ,jedinstvenim samoupravnim sporazumom fudbalskih klubova Prve savezne lige". 48

Za rješavanje sporova nastalih u vezi s ugovorima između igrača i kluba bila je nadležna posebna arbitraža kluba koja se sastojala od predstavnika radne zajednice i uprave kluba, sukladno članku 41. Pravilnika o statusu igrača NSJ-a.

$\mathrm{U}$ skladu s proklamiranom teorijom o odumiranju države i afirmaciji zajednice proizvođača te razvitkom samoupravljanja na svim poljima, Ustavom iz 1974. uvedeno je samoupravno sporazumijevanje i društveno dogovaranje. Tim sporazumima i dogovorima, kako je odredio članak 120. Ustava SFRJ ,[...] radnici i drugi radni ljudi samoupravno uređuju međusobne odnose, usklađuju interese i uređuju odnose od šireg društvenog značaja." Dok su se samoupravni sporazumi (SAS) ponajprije odnosili na gospodarstvo (udruženi rad) i društvene djelatnosti (SIZ) u vezi s međusobnim odnosima i podjelom sredstava, društveni dogovori odnosili su se i na društvene organizacije. Društvenim dogovorom su njegovi sudionici uređivali društveno-ekonomske i druge odnose od šireg zajedničkog interesa za sudionike ili od općeg društvenog interesa. ${ }^{49}$

Klubovi Prve savezne lige, prema našem mišljenju, na pravno upitnom temelju članka 388. Zakona o udruženom radu, zaključili su Samoupravni sporazum o udruživanju u Zajednicu fudbalskih klubova Prve savezne lige. ${ }^{50}$ Naime, člankom 388. stavkom 1. ZUR-a bilo je predviđeno da:

„Radnici mogu samoupravnim sporazumom udružiti svoje organizacije udruženog rada u poslovnu zajednicu kada su, da bi ostvarili svoje djelatnosti i razvoj, proizvodno, radno ili poslovno povezani radi zajedničkog utvrđivanja podjele rada, međusobnog unapređivanja uvjeta rada i poslovanja, ispitivanja tržišta, usklađivanja proizvodnje određene robe i usluga, zajedničkog istupanja na domaćem i stranom tržištu, znanstvenoistraživačkog rada, obrazovanja kadrova, zdravstvene zaštite te radi ostvarivanja drugih određenih zajedničkih interesa u radu i poslovanju.“

Stavkom 3. istog članka bilo je utvrđeno da se u poslovnu zajednicu mogu udruživati i poljoprivredne zadruge i drugi oblici udruživanja poljoprivrednika i druge zadruge.

S obzirom na to da nogometni klubovi, uključujući i one koji su zaključivali ugovore s profesionalnim igračima, nisu bili niti organizacije udruženog rada niti zadruge, upitno je kako su mogli zaključiti samoupravni sporazum o stvaranju poslovne zajednice temeljem članka 388. ZUR-a. Odgovor je bio u tomu da su i NSJ i prvoligaški klubovi bili svjesni tog formalnog propusta, ali da je način poslovanja klubova s profesionalnim igračima bio toliko sličan privrednim organizacijama (OURima) da su imali potrebu zaključiti takav samoupravni sporazum kojim su osnovali zajednicu. U Sporazumu je u članku 2. dana definicija Zajednice:

48 Ibid., cit. 22.

49 Ustav SFRJ iz 1974, Službeni list, br. 9/74, čl. 124. st. 1.

50 Samoupravni sporazum o udruživanju u Zajednicu fudbalskih klubova Prve savezne lige, Beograd, Zbirka propisa, Fudbalski savez Jugoslavije, 1981., Arhiva Hrvatskog nogometnog saveza. 
„Zajednica fudbalskih klubova Prve savezne lige je samoupravna, društveno sportska organizacija. Nastala je iz potrebe klubova da udruživanjem obezbede sprovođenje takmičenja, uređenje odnosa koji nastaju u vezi s takmičenjem i da doprinesu istovremeno utvrđivanju opšte politike razvoja, organizacije i unapređenje fudbalskog sporta na teritoriji SFRJ.“

Kao što se može vidjeti, ova zajednica nema mnogo zajedničkog s poslovnom zajednicom čije je osnivanje predviđeno člankom 388. ZUR-a. ${ }^{51}$

Napominjemo da je Udruženje klubova Prve savezne lige postojalo od 1966., a da je navedenim SAS-om formirana poslovna zajednica klubova.

Zajednica klubova, republički i pokrajinski nogometni savezi u okviru NSJ-a 1975. godine zaključili su „Društveni dogovor o osnovama samoupravnog organizovanja i načelima finansiranja fudbalskog sporta u Prvoj saveznoj fudbalskoj ligi“"(dalje: Dogovor). ${ }^{52}$

Dogovorom je dana definicija profesionalnih nogometaša kao radnih ljudi koji se u vidu zanimanja bave igranjem nogometa. Profesionalni nogometaši igranjem nogometa u klubu ostvaruju „osobni dohodak“ i druga primanja, a koja ovise o rezultatima i uspjesima koje postižu u natjecanjima. ${ }^{53}$ Pritom najviši „osobni dohodak“ profesionalnog nogometaša, koji će biti utvrđen SAS-om klubova Prve savezne lige, ne može biti veći od najvećeg iznosa „osobnog dohotka“ radnika u udruženom radu na području republike ili pokrajine u kojoj je sjedište kluba, ako je takav iznos utvrđen relevantnim propisima. Međutim, u taj maksimalni iznos nisu se ubrajali dohodci nogometaša koji su ostvareni kao nagrada za postignute uspjehe u domaćim i međunarodnim natjecanjima. ${ }^{54}$ Klubovi su bili obvezni nogometašima omogućiti školovanje, stručno osposobljavanje i pripremanje za odgovarajući životni poziv, a s druge je strane nogometaš bio obvezan osposobiti se za životno zanimanje. ${ }^{55}$

Klubovima su bili propisani i, tzv. stručno-materijalni uvjeti koji su morali biti ispunjeni da bi klub mogao imati profesionalne igrače i sudjelovati u prvenstvu Prve lige. Uvjeti se odnose na terene za igru (osigurana najmanje dva terena, od kojih jedan s travom), svlačionice, ambulantu, stručni trenerski kadar (od toga najmanje tri trenera u radnom odnosu na neodređeno vrijeme), registrirane igrače (najmanje 100) mlađih uzrasta i reflektore za igranje noćnih utakmica. ${ }^{56}$

Temeljem navedenog Dogovora, klubovi Prve savezne lige 1975. zaključili su „Samoupravni sporazum o pravima i obavezama klubova Prve savezne lige u vezi sa samoupravnim organizovanjem i nagrađivanjem profesionalnih fudbalera“, koji se

51 Kao zanimljivost spomenimo, danas bizarno za jednu sportsku organizaciju, da je jedan od zajedničkih ciljeva udruživanja klubova bilo ,jačanje odbrambene sposobnosti zemlje i njegovanje tradicija Narodnooslobodilačke borbe“ (članak 3. točka 4. Samoupravnog sporazuma). Međutim, u tadašnje vrijeme ta je odredba bila u skladu s proklamiranom koncepcijom sustava općenarodne obrane i društvene samozaštite (ONO i DSZ).

52 Društveni dogovor o osnovama samoupravnog organizovanja i načelima finansiranja fudbalskog sporta u Prvoj saveznoj fudbalskoj ligi, Zbirka propisa, Fudbalski savez Jugoslavije, Beograd, 1981., Arhiva Hrvatskog nogometnog saveza (dalje: Dogovor).

53 Dogovor, čl. 2., st. 1. i 2.

54 Dogovor, čl. 8., st. 1. i 2.

55 Dogovor, čl. 14. i 15.

56 Dogovor, čl. 13. 
primjenjivao od početka natjecateljske godine 1977./1978., odnosno od 1. kolovoza 1977. (dalje: Sporazum 1975.). ${ }^{57}$

$\mathrm{Za}$ „osobne dohotke“ i druge dohotke nogometaša te za ispunjenje obveza klubova u vezi s isplatama u svakom se klubu formirao posebni fond čiji su izvori bili redovni prihodi kluba, namjenska društvena sredstva (dobivena od SIZ-a i "doprinosi“" OUR-a) i posebni prihodi (prihodi od nagrada za rezultate, prihodi od naknada za prelazak igrača, naknade za sudjelovanje igrača u reprezentacijama itd.). Od namjenskih društvenih sredstava $u$ fond za profesionalne igrače mogao se unijeti samo iznos koji je samoupravnim sporazumom ili ugovorom s davateljem tih sredstava bio dogovoren. Sredstva posebnog fonda mogla su se koristiti, osim za isplatu profesionalnih igrača, za njihovu zajedničku potrošnju (osiguranje stanova, ishranu, godišnje odmore i druga davanja koja su se po propisima o organizacijama udruženog rada priznavali kao izdatci zajedničke potrošnje). Osobito je zanimljivo da su se sredstva posebnog fonda koristila i za izvršavanje obveza prema društvenoj zajednici $\mathrm{u}$ vezi $\mathrm{s}$ primanjima profesionalnih nogometaša ako propisima nije predviđeno da te obveze plaća profesionalni nogometaš. ${ }^{58}$ Uzevši u obzir odredbu Pravilnika o statusu igrača da profesionalni nogometaš ima pravo na uplatu socijalnih davanja, a što je utvrđeno i člankom 40. Sporazuma 1975., to znači da su klubovi uplaćivali mirovinsko i zdravstveno osiguranje u ime igrača iako nije bio s klubom u radnom odnosu.

Osobna primanja nogometaša ovisila su o vremenu koje je proveo u klubu, broju nastupa za jugoslavensku „A“ reprezentaciju u protekloj godini i uspjesima kluba u domaćim i međunarodnim natjecanjima. Sukladno navedenom, prihodi su nogometaša imali stalni i promjenjivi mjesečni dio, od čega stalni dio nije mogao biti viši od $40 \%$ od ukupnog najvišeg primanja. ${ }^{59}$ Najviši osobni dohodak profesionalnih nogometaša u tekućoj godini odgovarao je prosječnom mjesečnom jugoslavenskom osobnom dohotku (plaći) iz prethodne godine radnika u udruženom radu, pomnoženom $\mathrm{s}$ koeficijentom pet, ali sukladno Društvenom dogovoru, nije mogao prijeći najviši iznos osobnog dohotka u republici ili pokrajini ako je taj iznos utvrđen. ${ }^{60}$ Bio je propisan i najniži stalni mjesečni dohodak nogometaša, koji nije mogao biti niži od propisanog minimalnog dohotka radnika u udruženom radu odgovarajuće republike ili pokrajine. ${ }^{61}$

Dnevni, tjedni i godišnji odmor nogometaša regulirao se klupskim općim aktima temeljem propisa o odmoru radnika u udruženom radu. ${ }^{62}$

Tijekom jedne natjecateljske godine (natjecateljska godina je tada trajala od 1. kolovoza do 31. srpnja sljedeće godine) klub je pod ugovorom mogao imati najviše 30 profesionalnih igrača.

57 Samoupravni sporazum o pravima i obavezama klubova Prve savezne lige u vezi sa samoupravnim organizovanjem i nagrađivanjem profesionalnih fudbalera, Zbirka propisa, Fudbalski savez Jugoslavije, Beograd 1981., Arhiva Hrvatskog nogometnog saveza.

58 Sporazum 1975., čl. 9.

59 Sporazum 1975., čl. 14.

60 Sporazum 1975., čl. 15.

61 Sporazum 1975., čl. 16.

62 Sporazum 1975., čl. 46. 
Osim prihoda utvrđenih ugovorom i općim aktima kluba, igrač koji je prelazio $\mathrm{u}$ inozemni klub imao je pravo na naknadu od najmanje $50 \%$ od ugovorenog iznosa naknade ${ }^{63}$ Ugovori se nisu mogli zaključivati u trajanju kraćem od četiri godine, a prvi ugovor u trajanju od šest godina, osim ako se klub i igrač nisu drukčije dogovorili. ${ }^{64}$ Kako bi se spriječila nelojalna konkurencija, klubovi su se obvezali da prvi profesionalni ugovor neće zaključiti s igračem koji je „odgojen“ u drugom klubu, osim ako taj drugi klub ne da suglasnost.

Ugovorne strane nisu mogle raskinuti ugovor bez opravdanog razloga, a ako bi to napravio igrač, ne bi se mogao registrirati za drugi klub. Međutim, ponekad su igrači nastojali prijevremeno raskinuti ugovor i prijeći u drugi klub i bez dopuštenja sadašnjeg kluba. U tim pokušajima su se pozivali na Ustav i zakone. Tako je igrač Hajduka Miroslav Bošković u srpnju 1973. za tisak izjavio:

„Ostajem dosljedan svojoj odluci da se preselim u Beograd. Razlozi su svima dobro poznati. Ne želim rušiti brak. Ako mi 'Hajduk' ne izađe u susret i izda ispisnicu, zaposlit ću se i čekati rasplet svoga slučaja. Kako sam već jednom rekao, svoja prava tražit ću putem redovnog suda, a ako bude potrebno i do Ustavnog suda. Uvjeren sam da ću svoja prava izboriti. Ovo mi je prilika da kao student prava još bolje proučim Ustav i ostale naše pozitivne zakone."،65

Hajduk je i bez Ustavnog suda dao ispisnicu te je Bošković karijeru nastavio u Partizanu.

Profesionalni odnos između kluba i igrača, osim proteka vremena na koji je ugovor zaključen ili sporazumom, prestajao je i kada nadležno tijelo kluba utvrdi da je taj odnos prestao krivnjom kluba ili igrača. Na klupsku odluku igrač je imao pravo žalbe posebnom tijelu Zajednice klubova, a ako je bio nezadovoljan tom odlukom, mogao je podnijeti tužbu nadležnom sudu. ${ }^{66}$

Važno je uočiti da su, unatoč samoupravljačkim pravima profesionalnih nogometaša unutar kluba, ovaj Sporazum kojim se definiraju i razrađuju prvenstveno prava i obveze nogometaša, zaključili sami klubovi te da igrači niti njihov savjet profesionalnih nogometaša nisu sudionici Sporazuma. Naravno, Sporazum je zaključen temeljem Statuta i Pravilnika o statusu igrača NSJ te Društvenog dogovora između republičkih i pokrajinskih nogometnih saveza i Udruženja klubova Prve savezne lige, ali to ne mijenja na činjenici da predstavnika nogometaša nema u Sporazumu.

Konačni formalni produkt svih ovih propisa bio je ugovor između kluba i igrača.

Za analizu ugovora između kluba i igrača uzet ćemo primjer ugovora koji je igrač V. M. zaključio s Fudbalskim klubom Napredak iz Kruševca (Srbija) 1972. godine. Zašto baš taj ugovor, bez obzira na to što je zaključen prije navedenog Društvenog dogovora i Samoupravnog sporazuma klubova? Njegovom analizom utvrđeno je da ima većinu elemenata koji su utvrđeni navedenim općim aktima, a osim što sadrži neke zanimljive klauzule, taj je ugovor bio predmet ispitivanja Međurepubličke komisije koju je osnovao Izvršni odbor NSJ-a u rujnu 1973. godine, nakon što je

63 Sporazum 1975., čl. 38.

64 Sporazum 1975., čl. 23

65 Slobodna Dalmacija od 3. 07. 1973.; cit. prema: Gizdić, op. cit., str. 59.

66 Sporazum 1975., čl. 45. 
prvenstvo Prve savezne lige 1972./73. završilo s velikim sumnjama u regularnost pojedinih utakmica.

Od, tzv. „afere bunde“ u kojoj je FK Spartak Subotica platio sucima utakmice Spartak-Budućnost (Titograd) bunde, kasnijeg početka odlučne utakmice Olimpija (Ljubljana) - Partizan (Beograd), vjerojatno namještene utakmice Partizan-Bor, navodno nepravilnog nastupa igrača na utakmici Dinamo-Olimpija, pa do očitih pogrešaka sudaca na nekoliko bitnih utakmica, nanizalo se mnogo nepravilnosti u spomenutom prvenstvu. ${ }^{67}$ Nakon prvih rezultata istrage Međurepubličke komisije Izvršni odbor NSJ-a donio je odluku o raspuštanju svih tijela Saveza nogometnih sudaca Jugoslavije, a predsjednik te Komisije B. Perović izjavio je za tisak:

„Posjedujemo dovoljno dokaza i izjava ljudi na koje se možemo osloniti, jer oni su komunisti, dugo su u sportu, pa im moramo vjerovati. Ima priličan broj odluka koje nisu smjele biti donesene, ima primjera da su pojedinci radili ne za nogomet, nego protiv njega [...] Bit će pronađeni ljudi koji su 'vršljali' u nogometu i nogometnim organizacijama. Jer, nama je naloženo da očistimo nogomet od prljavštine i nama kao komunistima je to osnovni zadatak. “68

U prosincu 1973. godine Međurepublička komisija podnijela je izvješće Izvršnom odboru NSJ-a o utvrđenom stanju i predložila izricanje sankcija nekim klubovima i pojedincima. Između ostalog, predloženo je kažnjavanje jednog od članova, tzv. „velike četvorke“ jugoslavenskog nogometa, beogradskog Partizana, s oduzimanjem šest bodova. ${ }^{69}$ U izvješću Međurepubličke komisije naveden je i FK Napredak iz Kruševca. Taj je klub, pri održavanju seminara sudaca i kontrolora suđenja Prve i Druge lige u Kruševcu naručio i platio 162 kožne putne torbe od lokalnog poduzeća te ih podijelio sucima i kontrolorima. Osim toga, Napredak je snosio troškove svečane večere, pansiona i putne troškove za sudionike seminara te im je darovao ukupno 88 kompleta sudačke opreme i 66 specijalnih satova. Međutim, Međurepublička komisija nije optužila Napredak za podmićivanje sudaca, već za kršenje propisa o materijalnofinancijskom poslovanju. ${ }^{70}$

Druga nepravilnost koju je Međurepublička komisija uočila u poslovanju Napretka bila je odluka o dodjeli stana u vlasništvo igraču V. M. ${ }^{71}$ Naime, taj je igrač

67 Sergej Gerc, Crna strana YU nogometa, Gospić, Centar Gospić, 1982., str. 144-147.

68 Ibid, str. 148.

69 Ibid, str. 150-151.

70 Ibid, str. 153.

71 Kao primjer da je politika bila vrlo zainteresirana za stanje u nogometu, uzet ćemo zapisnik s proširene sjednice Izvršnog odbora općinske konferencije SSRN Kruševac koja je sazvana radi razmatranja izvješća Međurepubličke komisije. Sjednici su osim članova IO Općinske konferencija SSRN prisustvovali i predsjednik Skupštine Općine, predstavnici Općinskog komiteta Saveza komunista Srbije, Općinske konferencije Saveza socijalističke omladine, sindikata i Općinske organizacije Saveza udruženja boraca Narodnooslobodilačkog rata. U nekim zaključcima sa sjednice vidi se visoka politiziranost sporta. Npr., jedan od zaključaka je da se preporuči upravi FK Napredak da redovnu skupštinu održi u roku od mjesec dana, a da pri izboru osoba u upravu treba ,poštovati stavove kadrovske politike Saveza komunista Jugoslavije“. Zatim se smatra značajnim da se u FK Napredak što prije osnuje aktiv Saveza komunista i Saveza omladine te da se formira samoupravna radnička kontrola. Ističe se i važnost javnosti u radu, što ,spada u broj važnijih i značajnijih zadataka iz Pisma i govora 
prvi ugovor s Napretkom potpisao 1969. godine u trajanju od četiri godine, a 1971. i 1972. ugovor je produžavao na daljnje četiri godine. U ugovoru zaključenom 16. ožujka 1972. godine stoji da je „Za potpis ovog produženog četverogodišnjeg ugovora Klub u obavezi da V. M. dodeli trosobni komforan stan u trajno korišćenje“ ${ }^{72}$ Pritom je ispred riječi „korišćenje“ bila upisana riječ „vlasništvo“, koja je precrtana. U nastavku ugovora utvrđeno je da ako igrač V. M. samovoljno napusti klub prije isteka četverogodišnjeg ugovora, obvezan je stan vratiti klubu. Ono što je Međurepubličkoj komisiji bilo sporno, jest činjenica da je temeljem ranijeg ugovora, od 16. ožujka 1971. godine ${ }^{73}$ igrač imao pravo na uporabu dvosobnog komfornog stana i namještaja u vrijednosti od 15.000,00 dinara. Međutim, jedan dan prije nego što je zaključen navedeni ugovor iz 1972. godine, 15. ožujka 1972. godine, FK Napredak donio je rješenje kojem se V. M., „aktivnom članu-fudbaleru ovog kluba“, kao nositelju stanarskog prava dodjeljuje u trajno vlasništvo trosoban komforan stan. ${ }^{74}$ Znači, osim što je rješenje doneseno prije zaključenja ugovora kojim igrač stječe pravo na dodjelu trosobnog stana (prema dosadašnjem ugovoru imao je pravo na dvosoban stan), igraču je dodijeljeno pravo vlasništva, a ne stanarskog prava (kao što stoji u ugovoru) na stan.

Ne ulazeći u kasnija objašnjenja i posljedice vezane uz ove događaje, analizirat ćemo ovaj ugovor između profesionalnog igrača i kluba.

Nakon utvrđenja da se ovim ugovorom ne zasniva radni odnos, nabrojene su dužnosti igrača. Trebao je nastupati za klub kada je bio određen igrati, ulagati sve svoje znanje i požrtvovanje tijekom utakmica i treninga, sportski se ponašati na igralištu i izvan njega te se skrbiti o svojoj tjelesnoj kondiciji i zdravlju.

$\mathrm{S}$ druge strane, klub je igraču trebao redovito isplaćivati mjesečne naknade te igraču koji je u radnom odnosu s drugom radnom organizacijom nadoknaditi izgubljeni dio plaće za vrijeme kada nije mogao biti na svom radnom mjestu zbog sudjelovanja na treninzima i utakmicama. Nadalje, klub je igraču snosio sve putne troškove kada se igrač nalazi izvan sjedišta kluba radi odigravanja utakmica, osiguravao mu je zdravstvenu skrb za ozljede koje je zadobio tijekom utakmica ili treninga i omogućavao igraču pohađanje škole i polaganje ispita, odnosno obavljanje poslova na radnom mjestu.

Temeljem ugovora igrač je bio raspoređen u prvu kategoriju prema Pravilniku o naknadama, premijama i nagradama igrača. Za potpis ugovora, klub se obvezao igraču dodijeliti trosobni komforan stan na trajno korištenje. Međutim, ako bi igrač

druga Tita.“U zaključku kojim se utvrđuje da društveno-političke organizacije u Općini trebaju pružati veću i sustavniju pomoć FK Napredak ističe se da klub obavlja i društvene funkcije. Zapisnik s proširene sjednice Izvršnog odbora općinske konferencija SSRN Kruševac, u: Ocene i mišljenja fudbalskih saveza republika i pokrajina o nalazima Međurepubličke komisija IO FSJ, Beograd, 1974., Arhiva Hrvatskog nogometnog saveza.

Nema razloga vjerovati da je drukčije bilo u ostalim republikama, uključujući i Hrvatsku.

72 Ugovor zaključen 16. ožujka 1972. između FK Napredak i V. M. u: Ocene i mišljenja fudbalskih saveza republika i pokrajina o nalazima Međurepubličke komisije IO FSJ.

73 Ugovor zaključen 16. ožujka 1971. između FK Napredak i V. M. u: Ocene i mišljenja fudbalskih saveza republika i pokrajina o nalazima Međurepubličke komisije IO FSJ.

74 Rešenje Fudbalskog kluba Napredak br. 180 od 15. 03. 1972. u: Ocene i mišljenja fudbalskih saveza republika i pokrajina o nalazima Međurepubličke komisije IO FSJ. 
samovoljno napustio klub prije isteka ugovora, obvezan je vratiti stan klubu. ${ }^{75}$

Prema iznesenome, može se uočiti da profesionalni nogometaši formalno nisu bili u radnom odnosu s klubom. Međutim, njihov status ima neke bitne značajke radnog odnosa. Prije svega, to je status naknade za rad. Statut NSJ-a govori o „odgovarajućoj novčanoj naknadi“ za igranje nogometa. Pravilnik tu naknadu precizira i određuje da se radi o osobnom odnosno „ličnom“ dohotku. U tadašnjoj terminologiji osobni (,lični“) dohodak je značio plaću radnika temeljem radnog odnosa. Zatim, tu su odredbe o radnom vremenu, dnevnom, tjednom i godišnjem odmoru i mirovinskom, zdravstvenom i invalidskom osiguranju. To su sve elementi iz radnog odnosa. Konačno, postoji i jedan od osnovnih elemenata radnog odnosa odnos subordinacije između kluba (odnosno njegove ovlaštene osobe, prvenstveno trenera) kao poslodavca i igrača kao radnika. Naime, klub (trener) odlučivao je hoće li igrač nastupiti, kakve su mu zadaće u igri, kada i kako će trenirati, hoće li i kada ići u, tzv. „karantenu“ (zajednički boravak ekipe prije utakmice) i sl. Igrač se obvezao poštovati radnu disciplinu, naloge i upute trenera, igrati i trenirati po svom najboljem umijeću, a za to je bio plaćen.

Opet, ugovori klub-igrač zaključivali su se na određeno vrijeme, nisu sadržavali ranije navedene uvjete iz Pravilnika i omogućavali su plaćanje naknade (novčanu ili materijalnu - stan, poslovni prostor) igraču za potpis ugovora, što bi za „obične“ radnike bilo nezamislivo. Stoga se može zaključiti da su profesionalni nogometaši imali status osoba koje se samostalno bave određenom djelatnošću, ali koji su u odnosu s klubom ostvarivali određena prava iz radnog odnosa. Pritom takav status nije bio određen državnim propisima već autonomnim pravom nogometne organizacije i društvenim dogovorom republičkih i pokrajinskih nogometnih saveza i Udruženja klubova Prve savezne lige.

\section{PRIJEDLOZI ZA SAMOUPRAVNI PREOBRAZ̆AJ KLUBA}

Člankom 13. Statuta NSJ-a određen je status nogometnog kluba unutar nogometne organizacije:

„Osnovna sportska samoupravna organizacija u kojoj fudbaleri - igrači, društveno-sportski radnici i drugi članovi ostvaruju svoju društveno-sportsku aktivnost u fudbalu, jeste fudbalski klub.“

Klub je, kao što smo vidjeli, bio registriran i ustrojen kao udruženje građana. Međutim, u klubovima Prve savezne lige koji su mogli zaključivati ugovore s profesionalnim nogometašima, bilo je i elemenata gospodarske organizacije (odnosno organizacije udruženog rada). Uz to, taj se hibrid nastojao premrežiti samoupravnim društvenim odnosima.

$\mathrm{Na}$ primjer, u spomenutom „Samoupravnom sporazumu o pravima i

75 Bilo je i drukčijih primjera. Tako je FK Partizan pravilnikom odredio da igrač i nakon odlaska iz kluba može zadržati stanarsko pravo na stan dobiven od kluba ako je bio njegov član određeno vrijeme. Tako je u Slobodnoj Dalmaciji od 15. 12. 1983. objavljeno da igrač Dževad Prekazi može zadržati stanarsko pravo na stan dobiven od Partizana i nakon prelaska u Hajduk jer je u Partizanu bio devet godina. Cit. prema: Gizdić, op. cit., str. 88. 
obvezama u vezi sa samoupravnim organiziranjem i nagrađivanjem profesionalnih nogometaša“, kao što mu već i naziv kaže, nastojalo se postići da igrači sudjeluju u samoupravljačkim procesima unutar kluba. Tako su se klubovi obvezali da će profesionalnim igračima omogućiti da upravljaju poslovima kluba koji su u vezi s njegovom sportskom aktivnosti, da biraju i budu birani u tijela kluba. S druge strane, obveza je igrača bila da se „osposobi za uspešno izvršavanje samoupravnih funkcija u klubu“. ${ }^{76}$ Nadalje, sukladno Sporazumu, svi profesionalni nogometaši u klubu formirali su posebnu zajednicu u čijem radu sudjeluju, bez prava odlučivanja, i treneri profesionalne momčadi i predstavnici uprave kluba te igrači amateri dok nastupaju s profesionalcima u službenim natjecanjima. Svoja samoupravna i druga prava profesionalni nogometaši ostvarivali su neposredno upravljajući tom zajednicom na njenom zboru. Profesionalni nogometaši birali su predsjednika zajednice koji je ulazio u izvršna tijela kluba i predstavljao je svoju klupsku zajednicu pri udruženju profesionalnih nogometaša u Zajednici kubova Prve lige. Zajednica je svoja prava trebala ostvarivati putem klupskih samoupravnih tijela. ${ }^{77}$

Međutim, da se radi o „mješovitom“ modelu pokazuje odredba da igrač ima prava koja pripadaju članu kluba. To znači da nogometaš nije bio samo osoba u ugovornom odnosu s klubom (koji je opet dvojak - samostalna djelatnost s elementima radnog odnosa), nego da je imao prava člana kao u „običnom“ udruženju građana.

Da se, barem na papiru, nije radilo o ,pravom“ profesionalizmu, odnosno da je taj profesionalizam prilagođenom društvenom sustavu u kojem je postojao, pokazuje i odredba kojom se profesionalni nogometaš obvezivao da će najkasnije u roku od šest godina od zaključenja prvog ugovora steći odgovarajuću kvalifikaciju za životno zanimanje, a klub se obvezao da će mu osigurati uvjete za stjecanje takve kvalifikacije. Istekom roka od šest godina profesionalni nogometaš koji se nije osposobio za neko životno zanimanje gubio je status profesionalca. ${ }^{78}$ Time se željela pokazati skrb za čovjeka i nastojalo se osposobiti nogometaše za radni život nakon profesionalne karijere.

Tijekom sedamdesetih godina prošlog stoljeća, još prije donošenja novog Ustava, primjećuje se pojačana tendencija da se samoupravljanje uvede u što većem opsegu u što većem broju subjekata. Niti nogomet nije bio iznimka. Izvještaj spomenute Međurepubličke komisije NSJ-a je dao republičkim i pokrajinskim savezima na očitovanje. Nogometni savez Hrvatske (dalje: NSH) 16. veljače 1974. godine poslao je svoj odgovor. Između ostaloga, Međurepublička komisija smatrala je da postoje nepravilnosti financijske prirode u prelasku igrača Branka Oblaka iz Olimpije u Hajduk. U svom odgovoru. NSH je priložio dopis Nogometnog saveza Dalmacije, kao svog regionalnog saveza, u kojem se odbacuju sve sumnje i optužbe Međurepubličke komisije. Ono što je zanimljivo, jedan od argumenata je bio da je:

„Hajduk među prvima od nogometnih klubova uspostavio i njegovao samoupravne odnose u klubu. Formirao je prije nekoliko godina dvije radne zajednice, omogućio neposrednim proizvođačima da budu zastupljeni u organima upravljanja

76 Sporazum 1975., čl. 41.

77 Ibid., čl. 43.

78 Ibid., čl. 27. 
i, što je najvažnije, da sami odlučuju o raspodjeli osobnog dohotka. Formirane su partijska i omladinska organizacija koje su vrlo brzo našle svoj puni smisao te koje već sada daju značajne rezultate. “79

Znači, nogometni klubovi su već uvodili samoupravljanje i dvije radne zajednice se vjerojatno odnose na zajednicu profesionalnih nogometaša i zajednicu stručnog i administrativnog osoblja kluba. Naime, radnici koji nisu bili neposredni proizvođači i koji obavljaju poslove od zajedničkog interesa za više organizacija u okviru radne organizacije formirali su radnu zajednicu. ${ }^{80}$ Nogometaši i administrativno i stručno osoblje bili su i u tijelima upravljanja, slično kao i u privrednim radnim organizacijama.

Među posebno apostrofiranim klubovima za malverzacije u izvještaju Međurepubličke komisije bila je ljubljanska NK Olimpija. Raspravljajući o izvještaju, tajništvo NK Olimpija izradilo je teze za reguliranje statusa kluba kao radne organizacije. Naime, NK Olimpija je smatrala, ako se želi sustavno regulirati status profesionalnog nogometa u Jugoslaviji, da se trebaju riješiti tri osnovna pitanja:

- konstituiranja nogometnog kluba kao radne organizacije;

- pitanje financiranja kluba i

- pitanje upravljanja klubom.

NK Olimpija predlagala je formiranje kluba kao radne organizacije, za što bi bila potrebna odluka nadležnog SIZ-a za fizičku kulturu koji bi procjenjivao je li „šira društvena zajednica zainteresirana da ima svog predstavnika u Prvoj saveznoj ligi““ ${ }^{81}$ Takva radna organizacija imala bi neke specifičnosti kao što je udruživanje profesionalne i amaterske djelatnosti te upravljanje klubom putem ,šire organizirane javnosti“ "koju bi predstavljali delegati SIZ-a, društveno-političkih zajednica, pojedinih radnih organizacija, društva prijatelja kluba i zaposlenih u klubu.

Kao izvori financiranja navedeni su prihod od ulaznica, SIZ, povremena reklamna djelatnost i redovni suosnivači. Predviđalo se da SIZ neće imati dostatno sredstava te bi zbog toga bilo potrebno zaključiti samoupravni sporazum s nekim radnim organizacijama koje bi financirale klub i imale status stalnih suosnivača kluba.

Skupština bi bila sastavljena po delegatskom sustavu u kojoj bi bili zastupljeni SIZ, stalni suosnivači kluba, zaposleni u klubu, društva prijatelja kluba i društvenopolitičke organizacije. ${ }^{82}$

Osobito je zanimljiv prijedlog da radna organizacija (pretpostavlja se iz privrede) putem SAS-a financira nogometni klub koji je i sam radna organizacija i zauzvrat dobiva određena upravljačka prava. Naime, ako na tren zanemarimo predviđeni utjecaj društveno-političkih organizacija, s obzirom na nepostojanje sredstava u SIZ-u, ovaj se prijedlog približio tržišnom modelu prema kojem bi dvije radne organizacije (u sportu i gospodarstvu) temeljem SAS-a razmjenjivale svoje usluge i sredstva, a ulagač

79 Dopis Nogometnog saveza Hrvatske Izvršnom odboru Nogometnog saveza Jugoslavije, br. 190/74 od 16. 02. 1974., u: Ocene i mišljenja fudbalskih saveza republika i pokrajina o nalazima Međurepubličke komisije IO FSJ.

80 Za kasnije razdoblje vidjeti definiciju u članku 29. i 30. Ustava SFRJ iz 1974.

81 Teze za regulisanje statusa fudbalskog kluba „Olimpija“ kao radne organizacije, prilog dopisu NK Olimpija Izvršnom odboru NSJ, broj 59/74 od 22. 01. 1974., u: Ocene i mišljenja fudbalskih saveza republika i pokrajina o nalazima Međurepubličke komisije IO FSJ.

82 Loc. cit. 
(,stalni suosnivač) bi imao prava suupravljanja sportskom radnom organizacijom.

Treba obratiti pažnju da se s navedenim tezama složio i Aktiv komunista u Predsjedništvu Gradske konferencije Saveza omladine Slovenije. Mladi komunisti Ljubljane dodali su još nekoliko dopuna, od kojih je jedna da financiranje i osobni dohotci u profesionalnom sportu moraju biti prilagođeni općim društveno-ekonomskim uvjetima društva i ne mogu prelaziti okvire društvenih normi. ${ }^{83}$

Rasprava o profesionalizmu u nogometu trajala je i sljedećih nekoliko godina. Tako je to bila i jedna od tema na IV. Redovnoj konferenciji NSJ-a koja se održala u prosincu 1977. godine. Pod već spomenutom točkom Aktuelna pitanja i zadaci fudbalske organizacije u pripremi platforme XI. Kongresa Saveza komunista Jugoslavije razmatrao se materijal „Stanje i problemi u masovnom i kvalitetnom fudbalu i pravci njihovog rešavanja“. U raspravi je istaknuto da nogometni klub, bez obzira na stupanj natjecanja, raspolaže s društvenim sredstvima i da je to jedan od bitnih elemenata za određivanje pravnog statusa kluba. To bi onda značilo da klub ima status ,društveno-pravnog, a ne građansko-pravnog lica kako se to uzima u praksi i u pravno-ekonomskom prometu“. ${ }^{84}$

Posebno valja istaknuti stav jednog delegata na Konferenciji:

„Mi danas imamo klubove saveznih liga koji se oslanjaju i koji su na određeni način vezani za pojedine veće privredne organizacije. Moraće stoga ubrzo da se reši pitanje da li se u jednoj organizaciji udruženog rada fudbalski klub može kategorisati kao osnovna organizacija udruženog rada, tako da njeni članovi igraju samo fudbal. Međutim, ako se organizaciono-pravno naš profesionalni fudbal tako postavio, onda bi teško mogao biti u tešnjim kontaktima sa sadašnjim i budućim kretanjima u ostalom delu fudbalskog sporta, pošto bi u tom slučaju postao jedna vrsta privredne delatnosti. To bi očigledno vodilo ka tome da bi profesionalni fudbal kao privredna delatnost bio odvojen od fizičke kulture, pa prema tome ne bi imao skoro nikakve veze sa sportom kao društvenom aktivnošću u najširem smislu reči.“"85

Zanimljivo je kako je nepoznati delegat Konferencije NSJ anticipirao razvoj i status profesionalnog nogometa ne samo u zemljama nasljednicama bivše Jugoslavije, nego u svijetu općenito.

Na Konferenciji je ukazano na pojave da se i u nižim ligama nogometašima plaćalo za igranje, odnosno da se , ,...] društveni dogovori o amaterizmu ne poštuju u svim republičkim i pokrajinskim savezima, s obrazloženjem da je stvar samoupravnih odluka pojedinih sredina koliko će davati igračima za bavljenje fudbalom [...]“.86

Ovdje se već radilo o pojavama koje su, obrazlagane pravom na samoupravljanje, dovodile u pitanje autoritet NSJ-a i njegove propise o mogućnosti legalnog plaćanja za igranje nogometa samo u Prvoj saveznoj ligi.

Nakon svih prijedloga i rasprava o potrebi promjena u pravnoj strukturi i obliku

83 Dopis Aktiva komunista u Predsjedništvu Gradske konferencija saveza omladine Slovenije upućen NK Olimpija od 27. 12. 1973., prilog dopisu NK Olimpija Izvršnom odboru NSJ, br. 59/74 od 22. 01. 1974., u: Ocene i mišljenja fudbalskih saveza republika i pokrajina o nalazima Međurepubličke komisije IO FSJ.

84 IV. Konferencija NSJ 1977., str. 17.

85 Loc. cit.

86 Ibid., str. 19. 
nogometnih klubova s profesionalcima, Izvršni odbor NSJ-a je na XXV. Redovnoj sjednici održanoj 17. travnja 1978. godine usvojio prednacrt Samoupravnog preobražaja nogometnog kluba. ${ }^{87}$

Taj dokument, podnaslovljen kao Teze za raspravu (dalje: Teze), dostavljen je republičkim i pokrajinskim nogometnim savezima na raspravu i dostavu mišljenja, prijedloga i dopuna do 20. svibnja 1978. godine.

Pisane samoupravnim metajezikom, Teze u uvodu ističu da nogometna organizacija zaostaje u odnosu na opći razvoj samoupravljanja, osobito za razvojem sustava samoupravnog udruženog rada temeljem Ustava i ZUR-a. To znači da je dosadašnji način organiziranja nogometne organizacije prevladan, što povlači i duboku krizu kluba kao osnovne nogometne jedinice. ${ }^{88}$

Kao prvi prijedlog konstituiranja kluba Teze su ponudile postojeći model udruženje građana. Ističe se da je do donošenja novog Ustava i ZUR-a društvenosportska aktivnost radnih ljudi i građana odvijala preko kluba koji je bio institucija temeljena na pravu građana na udruživanje. Međutim, taj klub ima i društvene elemente u pogledu masovnosti članstva i korištenja društvenih sredstava. Bez obzira na to, klub se po načinu nastanka svrstava u ,građansko-pravna lica, tj. udruženje građana, a ne u društveno-pravna lica, tj. u društvene organizacije“ ${ }^{89}$ Prema Tezama, klub treba postati institut samoupravnog prava, a ne klasičnog građanskog prava. Konačno, i „radnička klasa samoupravno organizovana u sistem udruženog rada“ zainteresirana je za razvoj sporta iz razloga izdvajanja društvenih sredstava OOUR-a u sport i radi osiguranja klasnog interesa radnika spajanjem rada i sporta, prevladavajući tendencije otuđenja sporta od udruženog rada..$^{90}$

Sljedeći prijedlog je klub kao društvena organizacija. Osim razloga navedenih kod preobrazbe iz udruženja građana, ističe se da klubovi u svojoj sredini ostvaruju društveno sportsku aktivnost od zajedničkog interesa za radne ljude i građane te da postoji potreba da se formiraju na samoupravnim temeljima i načelima delegatskog sustava. Stoga bi kod formiranja kluba dosadašnju volju skupine građana (koja osniva udruženje) trebala zamijeniti volja radnih ljudi i građana u općini ili gradu u kojima klub ima sjedište. Pritom bi rukovodeću strukturu u klubu birale skupštine sastavljene od delegata općinskih SSRN-a kao predstavnika radnih ljudi i građana. Kod ovog se prijedloga posebno ističe da OUR, čak i da osigurava poslovanje kluba, ne može biti konstitutivni element osnivanja kluba ,jer klub ne nastaje zbog udruživanja sredstava ili samo zbog ostvarivanja interesa i potreba radnika te OUR-a“, već ima širi društveni značaj i prelazi interese radnika pojedinog OUR-a. ${ }^{91}$

Prijedlog o klubu kao organizaciji udruženog rada odnosio bi se samo na klubove s profesionalnim nogometašima. Autori Teza smatrali su da osnovna načela Ustava i ZUR-a obvezuju da se i profesionalnim nogometašima u klubu osigura pravo

87 Prednacrt Samoupravnog preobražaja fudbalskog kluba - teze za raspravu, Beograd, Jugoslovenski fudbal, vanredni br. V, Nogometni savez Jugoslavije, 1978., str. 4-9. (dalje: Teze).

88 Teze, str. 4.

89 Loc. cit.

90 Ibid., str. 5.

91 Ibid., str. 7. 
na samoupravno organiziranje u svrhu uređivanja njihovih međusobnih odnosa uz osiguranje ponovnog uključivanja u sustav udruženog rada nakon završetka karijere. ${ }^{92}$ To bi se samoupravno organiziranje profesionalnih nogometaša moglo odvijati $u$ pravcu njihovog organiziranja u organizacije udruženog rada. Međutim, autori Teza smatraju da je to neostvarivo u postojećem društveno-ekonomskom sustavu jer bi temelj ostvarivanja dohotka takvog OUR-a koji bi bio dio sustava udruženog rada bio potpuno drukčiji od „običnog“ OUR-a. Nadalje, to bi značilo ukidanje kluba kao društvene organizacije te bi se još više povećale proturječnosti između sporta i rada. ${ }^{93}$

Ipak, unatoč a priori negativnom stavu, u Tezama se kao ravnopravan prijedlog, jednako kao i udruženje građana, našao i preustroj kluba u organizaciju udruženog rada, odnosno privredno poduzeće u sportu.

Četvrti je prijedlog bio mješavina društvene organizacije i elemenata ZUR-a. Sastojao se u tome da se unutar kluba kao društvene organizacije osnuje osnovna organizacija u koju bi se udružili profesionalni nogometaši. Da bi se moglo odgovarajuće primijeniti ZUR, cilj udruživanja nogometaša ne bi trebalo biti stjecanje i raspoređivanje dohotka već razvoj vrhunskog nogometa uz sprječavanje otuđenja sporta od rada i osiguranja samoupravnih prava nogometaša. ${ }^{94}$

Ta samoupravna prava su naknada osobnog dohotka, nagrada za sportski uspjeh, zdravstveno, mirovinsko i invalidsko osiguranje, pravo na dobivanje društvenog stana - što su sve prava iz radnog odnosa, odnosno ZUR-a. Međutim, nogometaš ne bi imao status radnika u udruženom radu i ne bi bio u radnom odnosu s klubom, nego bi svoja prava ostvarivao temeljem svoje profesionalne sportske djelatnosti na isti način kao i radnici u udruženom radu.

Radnici u udruženom radu, prema definiciji članka 6. ZUR-a bile su osobe koje rade društvenim sredstvima $u$ organizacijama udruženog rada, $u$ radnoj zajednici ili u drugom obliku udruživanja rada i sredstava. Ako bi pretpostavili da se radi o „drugom obliku udruživanja“, supsidijarno bi se primjenjivao članak 7. ZUR-a koji je utvrđivao da radni ljudi koji osobnim radom samostalno u obliku zanimanja obavljaju umjetničku ili drugu kulturnu, odvjetničku ili drugu profesionalnu djelatnost imaju na osnovu svog rada u načelu isti društveno-ekonomski položaj i u osnovi ista prava i obveze kao i radnici u organizacijama udruženog rada (što je zapravo odredba prenesena iz članka 31. Ustava SFRJ).

U zaključku Teza utvrdilo se da se za preustrojstvo nogometnog kluba kao institucije samoupravnog društva ne treba čekati donošenja novih zakona već se to može i treba napraviti u okvirima društvenog dogovaranja i samoupravnog sporazumijevanja, naravno uz odgovarajuću aktivnost SK i SSRNJ. ${ }^{95}$

Godine 1978., 11. studenoga održana je u Zagrebu VI. izborna sjednica Skupštine NSH. Jedna od točaka dnevnog reda bilo je razmatranje materijala NSJ-a koji su na javnoj raspravi, između ostalih i Samoupravni preobražaj nogometnog kluba. Dakle, gotovo šest mjeseci nakon isteka roka koji je NSJ ostavio za dostavu mišljenja NSH

92 Loc. cit.

93 Ibid., str. 8.

94 Loc. cit.

95 Ibid., str. 9. 
je razmatrao te materijale. Izvjestitelj na Skupštini bio je Zorislav Srebrić, delegat Zagrebačke regije. ${ }^{96}$

Srebrić je odbacio navode iz Teza da klubovi ne prakticiraju samoupravljanje jer su prvoligaši oponirali tom stavu i tvrdili da je samoupravna inicijativa realizirana barem u nekim oblicima. ${ }^{97}$ Nakon kratkog nabrajanja četiri predložena modela, iznosi da iz odgovora klubova proizlazi da se u slučaju drukčijeg načina rješavanja udruživanja od modela udruženja građana članstvu klubova treba omogućiti da u okviru delegatskog sustava izražavaju svoju volju. Vezano uz preustroj u društvene organizacije, Srebrić navodi da ostaje otvoreno pitanje Zakona o društvenim organizacijama koji je tek u prednacrtu. Stoga je za preobražaj iz udruženja građana u društveno-sportsku organizaciju jedina pravna osnova Ustav. Za treći prijedlog, konstituiranje kluba kao OUR-a, izlagatelj pronalazi slične zamjerke kao i autori Teza - ,[...] moglo bi doći u izvjesnom pravcu do toga da kroz djelatnost nogometnog kluba ne bude cilj razvijanje vrhunskog sporta nego stjecanje, stvaranje i raspodjela dohotka“".98 Kao četvrtu mogućnost, Srebrić je vidio kombinaciju koja omogućuje da klub bude sportsko-društvena organizacija, a nogometašima da se organiziraju kao radna zajednica kroz koju će ostvarivati svoja prava. Prema pristiglim očitovanjima u NSH, smatra da su klubovi najbliže verziji društveno-sportske organizacije. U vezi s prijedlogom profesionalnih nogometaša da im se u razdoblju od dvije do tri godine nakon prestanka sportske karijere omogući da od kluba i dalje primaju osobni dohodak, izlagač je istaknuo da mu se klubovi protive, osim ako tu obvezu ne bi preuzeo SIZ za zapošljavanje. ${ }^{99}$

U konačnici, za razliku od zaključaka Teze, Zorislav Srebrić smatrao je da se status kluba i profesionalnih igrača treba riješiti putem posebnog zakona, kao npr. $\mathrm{u}$ kazališnoj djelatnosti ili posebnim dijelom zakona u Zakonu o fizičkoj kulturi. ${ }^{100}$

Skupština je izlaganje bez rasprave primila na znanje, uz zaključak da se o toj materiji izjasni Savjet klubova Prve lige koji dolaze iz Hrvatske, kao i ostali klubovi saveznih i republičkih liga. Očito, NSH-u nije bilo pretjerano žurno iznijeti svoj konačni stav o tom pitanju.

\section{EPILOG ILI ŠTO JE BILO POSLIJE}

S obzirom na to da do ranih osamdesetih godina 20. stoljeća nije bilo izmjena spomenutih društvenih dogovora i samoupravnih sporazuma kojima su bili regulirani odnosi u profesionalnom nogometu, za pretpostaviti je da se ti odnosi nisu bitnije mijenjali.

U formalnom smislu, klubovi su ipak postali društveno-sportske organizacije. Primjerice, Statut NSH-a iz 1983. godine u članku 13. dao je definiciju kluba vrlo

96 Zorislav Srebrić bio je dugogodišnji dužnosnik NSH/HNS, NSJ i zagrebačkog Dinama, a od 1998. do 2012. bio je glavni tajnik HNS-a.

97 Stenografski zapisnik VI. Izborne sjednice Skupštine Nogometnog saveza Hrvatske održane 11. 11. 1978., str. 15, Arhiva Hrvatskog nogometnog saveza (dalje: Zapisnik 1978.).

98 Zapisnik 1978., str. 16-17.

99 Ibid., str. 19-20.

100 Ibid., str. 22. 
sličnu onoj iz Statuta NSJ-a:

„Nogometni klub je osnovna društveno-sportska i samoupravna organizacija u kojoj se razvijaju sportski i društveno- ekonomski odnosi. Osniva se na pravu i interesima radnih ljudi i građana na dobrovoljnoj osnovi“ ${ }^{101}$

Kao pokazatelj dugogodišnjeg nedovoljno definiranog statusa kluba u odnosu udruženje građana - društvena organizacija, navedimo i da su prema Statutu NSH-a iz 1968. godine (dakle i prije ustavnih promjena i Ustava iz 1974.) klubovi bili definirani kao „samoupravne društveno-sportske organizacije koje rade na osnovu svojih statuta donesenih u skladu sa ovim Statutom i statutima organizacija za fizičku kulturu i saveza područja“. ${ }^{102}$

Prema tomu, i u razdoblju kada su klubovi nedvojbeno imali formalni status udruženja građana, u službenim aktima nogometne organizacije bili su tretirani kao društvene organizacije.

Međutim, u definiciji iz 1983. godine postoji i vrlo znakovit dodatak - klub se označava i kao organizacija u kojoj se razvijaju društveno-ekonomski odnosi. To znači da se „priznalo“ da klub ima elemente gospodarske djelatnosti i da se kod njegovog djelovanja ne može raditi isključivo o sportskoj aktivnosti.

Zakon koji je spomenut na Skupštini NSH 1978. godine kao prednacrt, Sabor je donio 1982. pod nazivom Zakon o društvenim organizacijama i udruženjima građana. ${ }^{103}$

Člankom 2. tog Zakona napravljena je distinkcija između društvenih organizacija i udruženja građana: „U društvene organizacije udružuju se radni ljudi i građani radi ostvarivanja aktivnosti od šireg društvenog interesa, a u udruženja građana radi zadovoljavanja svojih osobnih i zajedničkih potreba“.

Društvene organizacije je moglo osnovati najmanje deset punoljetnih građana, s time da su iznimno osnivači i članovi mogli biti i zainteresirane društvene pravne osobe, ${ }^{104}$ što znači da bi, teoretski, osnivači kluba mogle biti i organizacije udruženog rada, kako je predlagao NK Olimpija.

Dva pravna entiteta razlikovala su se i prema izvorima financiranja. Društvene organizacije mogle su ostvarivati sredstva od članarine, od dotacija društvenopolitičkih zajednica i samoupravnih organizacija i zajednica, od priloga i darova, prihoda od igara na sreću, prihoda od imovine i prava, na osnovi samoupravno dogovorene naknade za izvršenje dogovorenog programa u samoupravnoj interesnoj zajednici te od prihoda od obavljanja privredne ili druge djelatnosti i od prihoda iz drugih izvora. ${ }^{105}$ Iz svih tih izvora mogli su se, i jesu, financirati i nogometni klubovi. Nasuprot tomu, da su klubovi ostali udruženja građana, mogli bi se financirati samo od članarine, od priloga i darova i drugih izvora u skladu sa zakonom. ${ }^{106}$

101 Statut NSH od 26. 02. 1983., Zagreb, Informativni bilten NSH, br. 3/83, Arhiva Hrvatskog nogometnog saveza.

102 Statut NSH od 30. 06. 1968., Zagreb, Službeni glasnik Saveza za fizičku kulturu Hrvatske, br. 89-90/1968., str. 6-10.

103 Zakon o društvenim organizacijama i udruženjima građana, Narodne novine, br. 7/82.

104 Ibid., čl. 14. i 15.

105 Ibid., čl. 19.

106 Ibid., čl. 23. 
Zakon o fizičkoj kulturi iz 1987. ${ }^{107}$ napravio je, barem u SR Hrvatskoj, bitan iskorak u davanju mogućnosti sportskim organizacijama u izboru oblika ustrojstva.

Prema tom Zakonu, radnici, radni ljudi i građani, radi organiziranog sudjelovanja u djelatnosti fizičke kulture, ostvarivanja i usklađivanja svojih interesa i samoupravnih prava u fizičkoj kulturi, mogli su se udruživati u sportske organizacije i organizacije za sportsku rekreaciju, a koje su imale status društvene organizacije ${ }^{108}$ Međutim, djelatnosti fizičke kulture (a to su između ostalih i djelatnosti treninga i natjecanja sportaša) mogle su obavljati i organizacije udruženog rada u oblasti fizičke kulture. ${ }^{109}$

Sportaši su sukladno Zakonu obavljali svoju djelatnost dobrovoljno i amaterski. Iznimno, sportaš je mogao zasnovati radni odnos radi obavljanja sportske djelatnosti ili tu djelatnost obavljati osobnim radom samostalno u vidu zanimanja. ${ }^{110} \mathrm{~S}$ obzirom na to da su sportsku djelatnost osobnim radom u vidu zanimanja mogli obavljati samo vrhunski sportaši u individualnim sportovima, ${ }^{111}$ profesionalni nogometaši mogli su samo zasnovati radni odnos s klubom. Republička zajednica za fizičku kulturu trebala je utvrditi sportske discipline i razinu natjecanja u kojima mogu nastupiti sportaši koji su zasnovali radni odnos. Ti su sportaši osnivali samostalno ili s drugim radnicima u sportskoj organizaciji radnu zajednicu. Međusobna prava i obveze između kluba i radnika-sportaša trebala su se urediti samoupravnim sporazumom. ${ }^{112}$

Ovim je zakonskim rješenjem zapravo prihvaćen četvrti model iz Teza, odnosno klub kao sportska društvena organizacija, unutar koje profesionalni nogometaši udružuju svoj rad u posebnoj zajednici.

Međutim, Zakon o fizičkoj kulturi ostavio je mogućnost i za primjenu trećeg prijedloga iz Teza - organizaciju udruženog rada u oblasti fizičke kulture. Zakon ne regulira detaljnije rad takvog OUR-a, osim što predviđa da je prije osnivanja osnivač dužan pribaviti suglasnost SIZ-a fizičke kulture o društvenoj i ekonomskoj opravdanosti osnivanja organizacije i predočiti dokaze o osiguravanju uvjeta za obavljanje djelatnosti. Ako je OUR u oblasti fizičke kulture bio od posebnog društvenog interesa, u upravljanju njegovim poslovima sudjelovali su i delegati zainteresiranih društveno-političkih i društvenih organizacija, organizacija udruženog rada i SIZ-ova. ${ }^{113}$

Nije nam poznato da je bilo koji nogometni klub koristio ovu mogućnost $\mathrm{i}$ ustrojio se kao organizacija udruženog rada u oblasti fizičke kulture.

Iako je Zakon o fizičkoj kulturi predvidio da sportaš može, iznimno, zasnovati radni odnos na određeno vrijeme, ${ }^{114}$ nije detaljnije uredio prava sportaša iz radnog odnosa. Stoga su se na profesionalne sportaše u radnom odnosu trebale primjenjivati odredbe Zakona o udruženom radu i Zakona o radnim odnosima radnika u udruženom

107 Zakon o fizičkoj kulturi, Narodne novine, br. 22/87.

108 Ibid., čl. 2.

109 Ibid., čl. 3.

110 Ibid., čl. 34 .

111 Ibid., čl. 41. i 44., st. 1.

112 Ibid., čl. 40.

113 Ibid., čl. 62.

114 Ibid., čl. 38., st. 2. 
radu. ${ }^{115}$ Naime, odredbe potonjeg Zakona primjenjivale su se i na radne odnose radnika u radnim zajednicama društvenih organizacija. ${ }^{116}$ To znači da bi za zasnivanje radnog odnosa s nogometašem klub trebao raspisati natječaj, ${ }^{117}$ trebao bi poštovati opće odredbe o radnom vremenu i dnevnim, tjednim i godišnjim odmorima, ne potraživati naknade nakon odlaska igrača u drugi klub, ne plaćati naknade za potpis ugovora te bi trebao uskladiti niz specifičnosti odnosa profesionalnog sportaša i kluba s općim odredbama o radnim odnosima.

Stoga su, s obzirom na to da takav specifičan radni odnos nije detaljnije reguliran, klubovi bili prisiljeni ne pridržavati se svih zakonskih odredbi o radnim odnosima.

\section{ZAKLJUČAK}

Početkom sedamdesetih godina 20. stoljeća jugoslavenski profesionalni nogomet prerastao je okvire koje mu je zadao tadašnji društveno-politički sustav. Postao je ozbiljna gospodarska djelatnost koja se, međutim, morala prilagoditi postojećim normama, ponajprije samoupravljanju i udruženom radu. Između ostalog, i zbog nesređenog pravnog statusa klubova i profesionalnih nogometaša, u jugoslavenskom je nogometu dolazilo do nepravilnosti i afera. Primjerice, profesionalni nogometaši nisu bili u radnom odnosu s klubovima, ali su im temeljem društvenih dogovora i samoupravnih sporazuma pripadala prava kao da su radnici. S druge strane, nogometaši su koristili povlastice (primjerice, naknada za potpis ugovora, dodjela poslovnog prostora, dodjela stana bez posebnih kriterija i bodovanja) koje radnici u udruženom radu nisu mogli ostvariti.

Stoga se nastojao pronaći model koji bi pomirio i potrebe sportskog profesionalizma i zahtjeve društveno-političkog sustava. Nakon višegodišnjih rasprava i iznošenja raznih prijedloga, Izvršni odbor NSJ-a usvojio je prednacrt prijedloga samoupravnog preustroja nogometnog kluba. Između četiri prijedloga, dva su sadržavala model prema kojem bi se nogometni klub ustrojio u potpunosti ili djelomično kao organizacija udruženog rada, odnosno na njega bi se primjenjivale odredbe ZUR-a. O predloženim modelima raspravljali su republički i pokrajinski nogometni savezi, ali se nije donijela nikakva odluka koja bi bitno promijenila odnose u jugoslavenskom profesionalnom nogometu. Tek nekoliko godina kasnije, 1982., nakon donošenja Zakona o društvenim organizacijama i udruženjima građana, klubovi su i formalno postali društvene organizacije u kojima su profesionalni sportaši bili izjednačeni s radnicima u udruženom radu te su ostvarivali svoja samoupravljačka prava. Zakonom o fizičkoj kulturi iz 1987. predviđena je mogućnost i da pravna osoba koja obavlja sportsku djelatnost ima oblik organizacije udruženog rada iz fizičke kulture. Međutim, nogometni klubovi nisu iskoristili tu mogućnost.

Profesionalni nogomet $\mathrm{u}$ društvu koje je politički i ideološki sport smjestilo u amatersku sferu kao sredstvo za tjelesno jačanje i rekreiranje novog socijalističkog čovjeka bio je strano tijelo koje se nastojalo prilagoditi društvenim i političkim

115 Zakon o radnim odnosima radnika u udruženom radu, Narodne novine, br. 11/78.

116 Ibid., čl. 2., st. 3.

$117 \mathrm{O}$ raspravi o natječajima za sportaše vidjeti Kovačić, op. cit., str. 88. 
pravilima, a istodobno koristiti sve praznine u tim pravilima, ponekad i za postizanje nedopuštenih ciljeva.

\section{LITERATURA}

\section{Knjige i članci}

\section{Knjige}

1. Bermejo Vera, José (ur.), Guía Juridica del Fútbol aficionado, Madrid, Real Federación Española de Fútbol, 1998.

2. Bilandžić, Dušan, Historija Socijalističke Federativne Republike Jugoslavije, Zagreb, Školska knjiga, 1979.

3. Bilandžić, Dušan, Moderna hrvatska povijest, Zagreb, Golden marketing, 1990.

4. Club Structures. A Guide to Club Stuctures for National League system and other Football Clubs London, Football Association - Charles Russell, 2010.

5. Gerc, Sergej, Crna strana YU nogometa, Gospić, Centar Gospić, 1982.

6. Gizdić, Jurica, U Hajduk su došli i u povijest ušli, Split, HNK Hajduk, 2010.

7. Kardelj, Edvard, Pravci razvoja političkog sistema socijalističkog samoupravljanja, Beograd, Izdavački centar „Komunist“, 1977.

8. Kramer, Fredi, Klemenčić, Mladen (ur.), Nogometni leksikon, Zagreb, Leksikografski zavod Miroslav Krleža, 2004.

\section{Članci}

1. Bilić, Andrijana, Smokvina, Vanja, Ugovori između profesionalnih nogometaša i klubova - ugovori radnog ili građanskog prava, Split, Zbornik radova Pravnog fakulteta u Splitu, vol. 49, 4/2012, str. 831-862.

2. Duke,Vick, Kickern Glasnost. Professionalisierung und Kommerzialisierung im tschechoslowakischen Fussball, u: Horak, Roman, Reiter, Wolfgang (ur.), Beiträge zur europäischen Fussballkultur, Wien, Promedia, 1991., str. 95-103.

3. Klasić, Hrvoje, Fiskultura u službi naroda. Uloga tjelesnog odgoja u stvaranju jugoslavenskog socijalističkog društva 1945.-1952., u: Duda, Igor (ur.), Stvaranje socijalističkog čovjeka, Zagreb, Srednja Europa, 2017., str. 201-220.

4. Klasić, Hrvoje, The Tito-Stalin Football War, Zagreb, Radovi - Zavod za hrvatsku povijest, vol. 48, 1/2016, str. 387-404.

5. Kovačić, Davor, Nogometni profesionalci u udruženom radu, Zagreb, Časopis za suvremenu povijest, 47-1/2016, str. 67-95.

6. Peročević, Katarina, Pojam „radnika“ u pravu Europske unije, Zagreb, Zbornik radova Pravnog fakulteta u Zagrebu, vol. 67, 2/2017., str. 319-343.

7. Prozumenščikov,Michail, Bemerkungen zum sowjetischen Fussball unter Stalin und Chruščev, u: Giessauf, Johannes, Iber, Walter M., Knoll, Harald (ur.), Fussball, Macht und Diktatur, Innsbruck, Studienverlag, 2014., str. 137-160.

8. Stanić, Igor, Sport za svakoga. Sportske aktivnosti radničke klase u Hrvatskoj od 1945. do početka 1960-ih, Zagreb, Historijski zbornik, vol. 69, 1/2017, str. 121-139.

\section{Vrela s inerneta}

1. Središnji državni ured za šport, Procjena učinaka Zakona o sportu. http://www.sdus.hr/ dokumenti-i-informacije/javno-savjetovanje/javno-savjetovanje-o-nacrtu-prijedlogaiskaza-o-procjeni-u\%C4\%8Dinaka-propisa-za-zakon-o-sportu/. Pristup ostvaren 11. 09. 2017.

2. Statut Njemačkog nogometnog saveza. https://www.dfb.de/fileadmin/_ dfbdam/128750-02_Satzung.pdf Pristup ostvaren 11. 09. 2017. 


\section{Pravni akti}

Bosna i Hercegovina

1. Zakon o sportu u Bosni i Hercegovini, Službeni glasnik BiH, br. 168/08.

Hrvatska, Republika (Socijalistička)

1. Ustav Socijalističke Republike Hrvatske, Narodne novine, br. 8/74.

2. Zakon o društvenim organizacijama i udruženjima građana, Narodne novine, br. 7/82.

3. Zakon o fizičkoj kulturi, Narodne novine, br. 22/87.

4. Zakon o fizičkoj kulturi, Narodne novine, br. 52/74.

5. Zakon o izmjenama i dopunama Zakona o sportu, Narodne novine, br. 85/15.

6. Zakon o radnim odnosima radnika u udruženom radu, Narodne novine, br. 11/78.

7. Zakon o sportu, Narodne novine, br. 71/06, 150/08, 124/10, 124/11, 86/12, 94/13 i 85/15.

8. Zakon o trgovačkim društvima, Narodne novine, br. 111/93, 34/99, 121/99, 52/00, 118/03, 107/07, 146/08, 137/09, 125/11, 152/11, 111/12, 68/13 i 110/15.

9. Zakon o udrugama, Narodne novine, br. 74/14 i 70/17.

10. Zakon o udruženjima građana, Narodne novine, br. 26/73.

Jugoslavija, Socijalistička, Federativna, Republika

1. Ustav Socijalističke Federativne Republike Jugoslavije, Službeni list SFRJ, br. 9/74.

2. Zakon o udruženom radu, Službeni list SFRJ, br. 53/76.

Srbija, Republika

1. Zakon o sportu, Službeni list Republike Srbije, br. 24/11.

Španjolska, Kraljevina

1. Ley del deporte 10/1990, de 15 de octubre, BOE, num. 249/1990.

\section{Građa}

Nogometni savez Hrvatske/Hrvatski nogometni savez

1. Pravilnik o statusu nogometnih klubova, Zagreb, Glasnik HNS, br. 57/08

2. Statut Nogometnog saveza Hrvatske od 26. 02. 1983. Zagreb, Informativni bilten NSH, br, $3 / 83$

3. Statut Nogometnog saveza Hrvatske od 30. 06. 1968., Zagreb, Službeni glasnik Saveza za fizičku kulturu Hrvatske, br. 89-90/1968.

4. Stenografski zapisnik VI. Izborne sjednice Skupštine Nogometnog saveza Hrvatske održane 11. 11. 1978.

Nogometni savez Jugoslavije

1. Društveni dogovor o osnovama samoupravnog organizovanja i načelima finansiranja fudbalskog sporta u Prvoj saveznoj fudbalskoj ligi, Beograd, Zbirka propisa, Fudbalski savez Jugoslavije, 1981.

2. Ocene i mišljenja fudbalskih saveza republika i pokrajina o nalazima Međurepubličke komisija IO FSJ, Beograd, 1974.

3. Pravilnik o statusu igrača Fudbalskog saveza Jugoslavije, Beograd, Zbirka propisa, Fudbalski savez Jugoslavije, 1981.

4. Prednacrt Samoupravnog preobražaja fudbalskog kluba - teze za raspravu, Beograd, Jugoslovenski fudbal, vanredni broj V, Nogometni savez Jugoslavije, 1978.

5. Samoupravni sporazum o pravima i obavezama klubova Prve savezne lige u vezi sa samoupravnim organizovanjem i nagrađivanjem profesionalnih fudbalera, Beograd, Zbirka propisa, Fudbalski savez Jugoslavije, 1981.

6. Samoupravni sporazum o udruživanju u Zajednicu fudbalskih klubova Prve savezne lige, Beograd, Zbirka propisa, Fudbalski savez Jugoslavije, 1981. 
7. Statut Fudbalskog saveza Jugoslavije, Beograd, Zbirka propisa, Fudbalski savez Jugoslavije, 1981.

8. IV Redovna Konferencija Fudbalskog saveza Jugoslavije, 17-18. 12. 1977, izvodi iz zapisnika, Beograd, Jugoslovenski fudbal, vanredni broj IV, Nogometni savez Jugoslavije, 1978.

Savez komunista Jugoslavije

1. Program SKJ, u: VII Kongres Saveza komunista Jugoslavije, Beograd, Kultura, 1958.

Savez za fizičku kulturu Jugoslavije

1. Savezna Skupština Saveza za fizičku kulturu Jugoslavije, Rezolucija o fizičkoj kulturi, Službeni glasnik Saveza za fizičku kulturu Hrvatske, br. 89-90/1968., str. 1-2.

Socijalistički savez radnog naroda Hrvatske

1. Mjesto i uloga društvenih organizacija, Teze radne grupe Republičke konferencije SSRN Hrvatske, Službeni glasnik Saveza za fizičku kulturu Hrvatske, Zagreb, broj 89-90/1968., str. 3-5. 


\section{Vladimir Iveta*}

Summary

\section{LEGAL STRUCTURE OF FOOTBALL CLUBS IN YUGOSLAVIA AND CROATIA WITH EMPHASIS ON THE EMPLOYMENT STATUS OF PROFESSIONAL FOOTBALL PLAYERS}

Today, football clubs are mostly associations or companies, while professional football players usually have the status of a worker or, in rarer cases, the status of an independent contractor. In socialist Yugoslavia and Croatia, sports were grounded in the principles of amateurism and socialist self-management. Professionalism in Yugoslav football was legalised in the 1960s, while, in the 1970s, it managed to fully establish itself and overcome the legal and sociopolitical frameworks that existed for amateur sports. Clubs became organisations that, in addition to sports activities, also conducted economic activities. This paper presents the attempts of the Football Association of Yugoslavia and republic-level and region-level federations at finding solutions to the opposition that had been created between professionalism and the governing system of socialist self-management and collective labour. It outlines the legal regulations that were in force at the time and analyses the proposals for changing the status of professional clubs and football players that were given by football federations and clubs. The paper also explains how the Football Federation failed to achieve an appropriate solution on its own, and how the regulation of the status of football players had to wait until the enactment of a relevant law. In the drafting of this paper, we used original sources created by the Football Association of Yugoslavia and Croatian Football Federation, as well as federal and republican regulations that were of relevance in the government of the stated matters.

Keywords: legal status of football clubs, Football Association of Yugoslavia, legal and labour status of football players, self-management, collective labour.

* Vladimir Iveta, dipl. iur., Croatian Football Federation; vladimir.iveta@hns-cff.hr. 
Zussamenfassung

\section{DIE RECHTSFORM DER FUSSBALLCLUBS IN JUGOSLAWIEN UND KROATIEN MIT BERÜCKSICHTIGUNG DES BESCHÄFTIGUNGSVERHÄLTNISSES VON FUSSBALLSPIELERN}

Während Fußballclubs heute meistens Vereine oder Handelsgesellschaften sind, haben professionelle Fußballspieler in der Welt den Arbeitsstatus, oder seltener, den Status der selbständigen Erwerbstätigkeit. Im sozialistischen Jugoslawien und Kroatien beruhte der Sport auf Amateurismus und sozialistischer Selbstverwaltung. Seit den 60er Jahren des 20. Jahrhunderts wurde Professionalismus im jugoslawischen Fußball legalisiert und in den 70er Jahren hat er sich völlig profiliert, so dass er den für den Amateursport vorgesehenen rechtlichen und gesellschaftlich-politischen Rahmen sprengte. Fußballclubs wurden zu Vereinen, welche neben der sportlichen auch die wirtschaftliche Tätigkeit ausübten. In dieser Arbeit stellt man den Versuch des Fußballverbands Jugoslawiens und der republikanischen und provinzlichen Verbände, die Gegensätze zwischen Professionalismus und dem herrschenden System des selbstverwaltenden Sozialismus und assoziierter Arbeit zu überwinden. Die Rechtsregulative wird in der Arbeit dargestellt und die von den Fußballverbänden und -clubs gegebenen Vorschläge für die Änderung des Status von professionellen Clubs und Fußballspielern werden analysiert. Es wird darauf hingewiesen, dass dem Fußballverband nicht gelungen ist, selbst die Lösung für die Regelung des Status von Fußballspielern zu finden, sondern man musste auf die Erlassung des relevanten Gesetzes warten. Bei der Erstellung dieser Arbeit stützte man sich auf die ursprünglichen Quellen, welche vom Fußballverband Jugoslawiens und Fußballverband Kroatiens geschaffen wurden, sowie auch auf die für die Regelung dieses Bereichs relevanten föderativen und republikanischen Vorschriften.

Schlüsselwörter: Rechtsstatus des Fußballclubs, Fußballverband Jugoslawiens, arbeitsrechtlicher Status des Fußballspielers, Selbstverwaltung, assoziierte Arbeit. 
Riassunto

\section{LA DISCIPLINA GIURIDICA DEI CLUB CALCISTICI NELLA JUGOSLAVIA SOCIALISTA ED IN CROAZIA CON ATTEZIONE PER LO STATUS GIUSLAVORISTICO DEI CALCIATORI PROFESSIONISTI}

Ad oggi i clubs di calcio sono perlopiù associazioni o società commerciali, mentre i calciatori professionisti sul piano globale hanno lo stato di lavoratori oppure, più raramente, di liberi professionisti. Nella Jugoslavia socialista ed in Croazia lo sport si fondava sui principi dell'amatorialità e del modello socialista di autogestione. Dagli anni sessanta del secolo scorso viene legalizzata la professionalizzazione del calcio jugoslavo; mentre negli anni settanta si affermò e prevalse per intero rispetto al quadro giuridico e politico che era fondato sull'idea dello sport amatariale. I clubs divennero organizzazioni che oltre ad attività sportive espletano anche attività commerciali. In questo lavoro si illustrerà il tentativo della Federazione calcio jugoslava, come anche delle Federazioni delle repubbliche e delle provincie di arrivare ad una soluzione nella contraddittorietà tra la professionalizzazione dello sport ed il sistema di autogestione e del lavoro collettivo socialista. Nel lavoro si passano in rassegna le normative e si analizzano le proposte che venivano date dalle federazioni calcio e dai clubs per il cambiamento dello stato dei clubs professionali e dei calciatori. Si dimostra come la Federazione calcio non è riuscita a trovare una soluzione adeguata e che per la regolamentazione dello status dei giocatori si dovette attendere l'emanazione della relativa legge. In occasione della stesura di questo lavoro sono state utilizzate le fonti originariamente create dalla Federazione calcio della Jugoslavia e dalla Federazione calcio della Croazia, come anche le leggi delle Repubbliche e Provincie che erano rilevanti per la regolamentazione di detta materia.

Parole chiave: Status giuridico dei clubs di calcio, Federazione calcio della Jugoslavia, status di diritto del lavoro dei calciatori, autogestione, lavoro collettivo. 